\title{
Financial Development and Output Volatility: A Cross-Sectional Panel Data Analysis
}

\author{
M. Tariq Majeed* and Ayesha Noreen ${ }^{* *}$
}

\begin{abstract}
This paper aims to provide a more comprehensive understanding of the impact of financial developments on output volatility. Using cross-sectional and panel datasets for 79 countries from 1961 to 2012, we find that financial expansion plays a significant role in mitigating output volatility, although the evidence is weak in some cases. The role of financial stability is more prominent than that of other measures of financial growth in mitigating output volatility. The volatility of terms of trade and inflation contributes positively to increasing output volatility. We also evaluate the channels through which financial developments can affect output volatility. Our model investigates the link between financial growth and output volatility through two potential channels, using four measures of financial development. The volatility of inflation and of terms of trade are used as proxies for monetary sector and real sector volatility, respectively. Financial development plays a mixed role in amplifying or mitigating output volatility through real and monetary sector volatility. Overall, there is some evidence to suggest that financial development amplifies monetary sector volatility, but weaker evidence that real sector volatility is reduced by financial development.
\end{abstract}

Keywords: Output volatility, financial development, panel data.

JEL classification: E30, E51, G20, O16.

\section{Introduction}

Over the past few decades, the concept of output volatility has gained greater attention among economists and policymakers. Figure 1 shows that output volatility does not follow a similar pattern across regions. It has declined over time in East Asia and the Pacific, Latin America and the Caribbean, North America, and the Middle East and North Africa. The reverse is true for Europe and Central Asia, sub-Saharan Africa and South Africa, where no clear pattern of output volatility is observable. Figure 2

\footnotetext{
* Assistant Professor, Quaid-i-Azam University, Islamabad, Pakistan.

** Lecturer, University of Wah, Wah, Pakistan.
} 
shows that countries with higher levels of economic development are less prone to output volatility. Numerous studies show that high output volatility tends to hinder growth and development (see, among others, Bruno \& Easterly, 1998; Loayza \& Hnatkovska, 2004; Aghion et al., 2004).

Figure 1: Output volatility across regions, 1961-2010

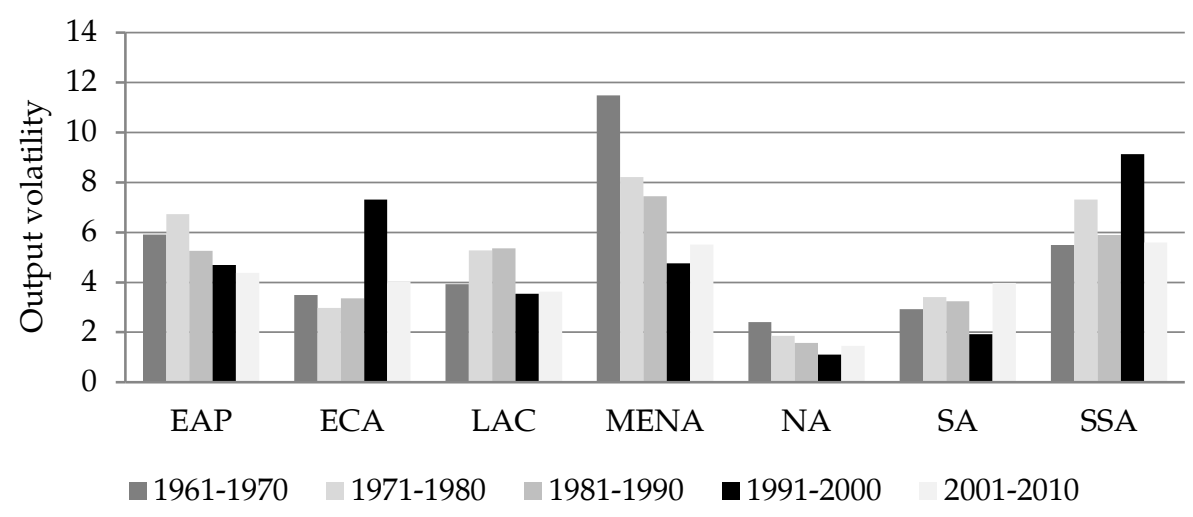

Note: Output volatility = four-year standard deviation of GDP per capita.

EAP $=$ East Asia and the Pacific, LAC = Latin America and the Caribbean, NA = North America, MENA = Middle East and North Africa, ECA = Europe and Central Asia, SSA = sub-Saharan Africa, $\mathrm{SA}=$ South Africa.

Figure 2: Output volatility, by income group, 1961-2010

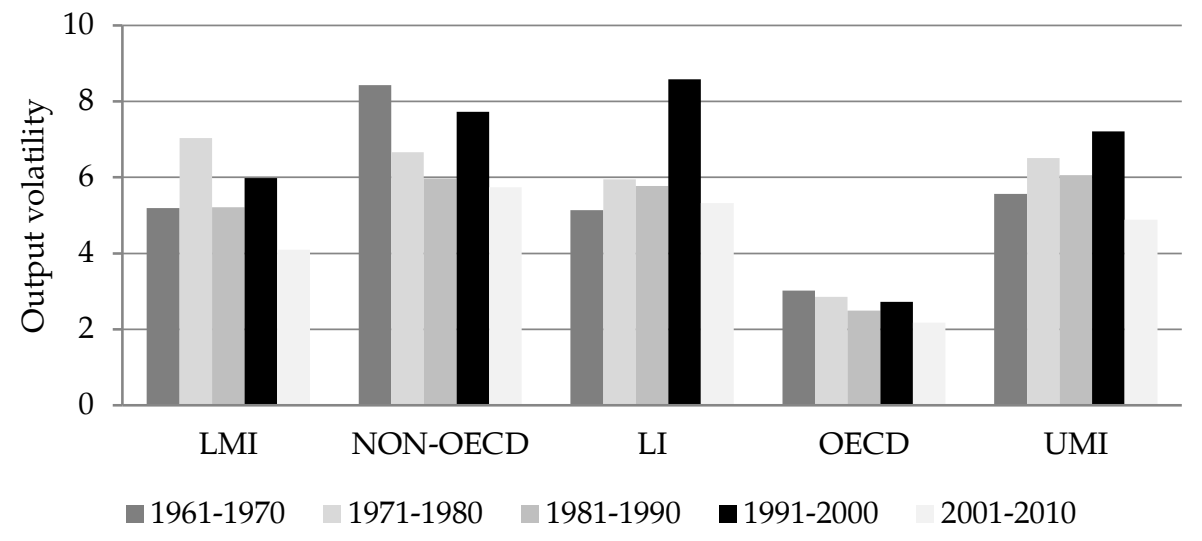

Note: Output volatility $=$ four-year standard deviation of GDP per capita.

$\mathrm{LI}=$ low-income, $\mathrm{LMI}=$ lower middle-income, $\mathrm{UMI}=$ upper middle-income.

There is broad agreement in the literature that high macroeconomic volatility tends to depress investment, is biased toward short-term returns 
and reduces economic growth (Servén, 2002). Recent work shows that higher macroeconomic volatility is also related to lower investment in human capital (Krebs et al., 2005). High output volatility and financial crises are recurring characteristics of many world economies, but they can be serious obstacles to development because they are closely related to high consumption volatility, high poverty, low long-term growth and high inequality. The literature recognizes that financial sector development has a positive impact on economic growth: a well-functioning financial market enables better relationships between investors and savers, promotes diversification, reduces risk, mitigates information asymmetries, encourages individuals to behave more effectively, and helps stabilize the economy and reduce output volatility (Ramey \& Ramey, 1995; Aghion et al., 2000).

In recent years, another important area of research has looked at what causes output volatility and how it can be mitigated. The literature examines different determinants of output volatility, including fiscal policy, consumption volatility, remittances, oil prices and foreign direct investment. While financial development is also a key determinant of output volatility, the literature in this area is not substantial and tends to yield ambiguous results. It is difficult to determine whether financial intermediary development leads to an increase or decrease in output volatility or if it helps reduce the impact of external shocks on the economy.

This paper attempts to identify the possible links between financial intermediary development and output volatility by examining whether financial intermediaries help absorb shocks - thereby reducing the effect of real and monetary volatility - or if they intensify the impact of such shocks. To the best of our knowledge, the relationship between output volatility and financial development has not been extensively researched. Therefore, this paper contributes to the literature by exploring the relationship between financial development and output volatility to determine whether financial development magnifies or reduces the volatility of output.

Additionally, the indicators of financial development used in previous studies do not provide a complete picture of the sector. While most studies have used the ratio of private credit to GDP as a proxy for financial development, this indicator does not include other characteristics such as financial depth, stability, access and efficiency. We use four measures of financial development: (i) the ratio of private credit to GDP (financial depth), (ii) net interest margin (financial efficiency), (iii) z-score (financial stability) and (iv) the number of bank branches per 100,000 adults (financial access). Besides looking at the relationship between financial development and 
output volatility, we also consider two potential channels through which the sector's development can affect output volatility - real sector volatility and financial sector volatility. Several pre-estimation tests and other diagnostics are used to ensure more reliable results.

The study tests the following hypotheses: (i) that the impact of financial development on output volatility is negative, and (ii) that the impact of financial development on output volatility varies depending on the measure used to gauge financial development. The finance-output volatility nexus may be explained better through the mechanism of shocks to the real and monetary sectors. Therefore, we also test a third hypothesis: that financial development has the power to mitigate or aggravate output volatility through real and monetary sector shocks.

The remaining study is organized as follows. Section 2 presents a literature review of studies on output volatility and financial development. Section 3 illustrates the analytical framework used. Section 4 presents the study's data and variables. Section 5 interprets and discusses the results obtained. Section 6 concludes the study, offering some policy implications.

\section{Literature Review}

The literature on the finance-and-growth nexus suggests that financial development has diverse effects on economic growth. An increasing number of studies indicate that a well-functioning banking system stimulates economic growth (see Goldsmith, 1969; Levine \& Zervos, 1998; Levine et al., 2000; Beck et al., 2000; Beck \& Levine, 2004). Other studies disagree: Lucas (1988), for instance, contends that finance is not an important determinant of growth. Similarly, Stern (1989) asserts that finance does not play a role in economic growth. The literature also points to the negative impact of financial development, as suggested by Keynes (1936) and supported empirically by De Gregorio and Guidotti (1995) and Andersen and Tarp (2003). Ram (1999) investigates the relationship between the growth of real GDP per capita and financial development, using panel data for 95 countries over the period 1960-89. The results indicate that financial development has a weak and negative or even negligible impact on the growth of real GDP per capita. Thus, the literature on finance and growth offers mixed results at best.

Although a large body of literature focuses on the growth effects of finance, few studies have examined in detail the potential links between financial development and the volatility of output. Mishkin (2009) 
emphasizes that, among other macroeconomic policy objectives, the stability of output growth is also very important. However, theory offers no clear predictions as to the effect of financial development on growth volatility. Bernanke and Gertler (1989), for example, argue that financial constraints to firms can play a vital role in the spread of business cycles, eventually leading to greater variations. On the other hand, studies such as Bacchetta and Caminal (2000), Aghion et al. (2004), Beck et al. (2006) and Ko (2008) argue that the negative or positive effect of financial development on volatility depends on monetary and real shocks, the stages of a country's financial development, and demand shocks or credit supply.

The empirical literature on finance and output volatility also presents mixed findings. For instance, Denizer et al. (2002) find that improved financial systems minimize fluctuations in per capita output growth. Similarly, Bekaert et al. (2006) observe that financial liberalization often results in lower (consumption) growth volatility. Ang (2011) shows that the implementation of financial repressionist policies is strongly associated with lower consumption volatility. Dynan et al. (2006) suggest that financial innovations contributed to stabilization in the mid-1980s and helped reduce output volatility.

Some empirical studies suggest that output volatility increases the effect of financial development. Bernanke and Gertler (1989) find that periods of financial distress correspond to periods of relatively high agency costs in investment. Financial constraints to firms can thus play a key role in the spread of the business cycle and eventually lead to greater variations. Similarly, Aghion et al. (2004) observe that countries undergoing financial development may become more unstable in the short run. Levchenko et al. (2009) find significant evidence to support the view that financial liberalization increases output volatility. Other empirical studies do not find a strong relationship between finance and output volatility. Acemoglu et al. (2003) establish that the volatility effect of financial development diminishes once institutional variables are controlled for. Similarly, Beck et al. (2006) find no robust relationship between financial development and aggregate economic volatility. Thus, the available empirical literature on finance and volatility does not provide a clear picture of this nexus.

The theoretical foundations of this study draw on four strands of the literature. The first, which relates to finance and development, argues that developed financial systems enhance the economy's ability to absorb shocks and help reduce output volatility. Most studies within this area are theoretical. For instance, Aghion et al. (1999) build a macroeconomic model 
that combines financial market imperfections with unequal investment opportunities. Their model predicts high output volatility in the absence of a developed financial sector. They argue that savers and investors are separated when the financial sector remains underdeveloped, and credit supply and demand is more cyclical. Investors are likely to be locked out of the credit market when the economy faces an adverse shock and to rush into the credit market when the economy absorbs a positive shock. In such situations, volatility is bound to increase.

Acemoglu and Zilibotti (1997) point out another important link between financial sector development and volatility by highlighting the importance of diversification in reducing risk. They argue that diversification is not possible in the early stages of development, given the indivisibility of capital. However, once wealth accumulates, diversification becomes possible and investment increases: in this situation, investment volatility and risk is reduced. Aghion et al. (2000) assess the role of open economies in explaining the volatility-finance nexus, arguing that volatility increases in open economies with intermediate levels of financial development.

The second strand of the literature explains the link between financial development and volatility through information asymmetries. Notable studies in this area include Bernanke and Gertler (1989), Greenwald and Stiglitz (1993), and Kiyotaki and Moore (1997). These studies develop general equilibrium models to show how asymmetries of information in financial markets exacerbate volatility.

The third strand of the literature highlights the importance of financial development in long-run macroeconomic performance. Studies such as Gertler (1988) and Levine (1997) show that financial development helps reduce the cost of acquiring information and facilitates lower transaction costs. The argument here is that financial development helps reduce information asymmetries, improves corporate governance and leads to better resource allocation. It also enables financial institutions to improve their risk management and allocate their liquidity and funds to the most productive uses (Greenwood \& Smith, 1997).

Finally, a fourth strand of the literature cautions against the adverse volatility-related consequences of financial sector development. Shleifer and Vishny (2010) and Wagner (2010) argue that financial development can cause over-leverage or induce greater risk-taking by entrepreneurs and banks, potentially driving up the level of volatility. Many recent studies 
show that, while financial intermediaries and institutions can help mitigate friction, amplification mechanisms within the financial sector and from the financial sector to the real sector can exacerbate volatility (for surveys of recent models, see Brunnermeier et al., 2012; Quadrini, 2011).

In sum, the literature demonstrates several potential routes through which financial development can affect output volatility. First, a more developed financial sector is likely to match savers and investors more efficiently, allowing the economy to absorb shocks more easily, thereby reducing volatility. Second, more financial markets and institutions facilitate diversification, which helps reduce risk and volatility. Third, financial development may be a proxy for information asymmetries, which themselves can cause increased volatility. This study contributes to the literature using four diverse indicators of financial performance: depth, efficiency, stability and access. It also presents two mechanisms - real sector and financial sector volatility - through which financial development can amplify or reduce output volatility.

\section{Methodology}

The global financial crisis has triggered policy debates on the role of finance in proliferating and decreasing macroeconomic fluctuations. The last two decades show that high output volatility can have an adverse effect on economic growth, welfare and poverty, particularly in developing countries (Ramey \& Ramey, 1995). The literature discussed in Section 2 outlines various ways in which financial development can affect output volatility. This is the starting point of our analysis.

While there is considerable empirical evidence on the determinants of output volatility, most of these investigations have focused on specific determinants of output volatility, with little uniformity in the sets of explanatory variables used. In recent years, the literature has also looked at how financial openness, financial integration, financial institutions and monetary policy can affect output volatility. Informal arguments suggest that the quality of financial institutions may be a key determinant of output volatility: sound financial institutions enable economies to better handle large output fluctuations.

In this study, we focus on financial development as a key determinant of output volatility. There are contrasting views on the role of financial development in economic growth and output volatility. On the one hand, the development of financial systems changes the incentives and 
constraints faced by economic agents by producing information, allocating capital and monitoring firms. Furthermore, financial developments help reduce risk, pool savings and ease exchange, with positive impacts on economic growth (Greenwood \& Jovanovic, 1990; Bencivenga \& Smith, 1991; King \& Levine, 1993; Acemoglu \& Zilibotti, 1997). On the other hand, Ko (2008) finds that economies characterized by financial liberalization have higher output volatility in the face of monetary policy shocks. Dynan et al. (2006) suggest that financial innovations contribute to long-term, not shortterm, declines in output volatility.

\subsection{Output Volatility Model}

Following the literature, our benchmark measure of volatility is the standard deviation (SD) of real per capita GDP (see Beck et al., 2000; Hakura, 2007; Malik \& Temple, 2009; Ahamada \& Coulibaly, 2011). It is also standard in the empirical literature to use the log of GDP per capita as a measure of growth to determine volatility (see Posch, 2011; Beck et al., 2006). Accordingly, we develop our model by introducing the following baseline regression:

$$
O V=\alpha_{1}(l G D P)_{i, t}+\beta_{1}(F D)_{i, t}+\delta(X)_{i, t}+\mu_{i}+\varepsilon_{i, t}
$$

where $O V$ is macroeconomic volatility, measured by the SD of the annual percentage growth rate of real GDP per capita based on constant 2005 US dollars, and lGDP is a measure of growth, denoted by the log of GDP per capita. FD represents financial development. $X$ is a control variable, trade openness, measuring the ratio of exports plus imports to GDP, following Kose et al. (2009). Finally, $\mu$ is a country-specific effect, $\varepsilon$ is the error term and $i$ and $t$ denote country and period, respectively.

To evaluate empirical predictions concerning the relationship between financial development and macroeconomic volatility, we would need to construct measures of the ability of financial systems to improve information asymmetries, ease risk management and smooth resource mobilization. Most other studies have used financial depth as the sole measure of financial development (see King \& Levine, 1993; Beck et al., 2000; Bacchetta \& Caminal, 2000; Denizer et al., 2002). Financial development is, however, a multidimensional concept and warrants more than one measure. A complete picture of financial development and its characteristics is presented by Čihák et al. (2012), who emphasize the importance of these characteristics in cross-county analyses. Our measure of financial development is based on these characteristics and comprises four 
components: depth (the ratio of private credit to GDP), efficiency (net interest margin), access (number of bank branches per 100,000 adults) and stability (z-score).

Closely following Beck et al. (2000), we study the responsiveness of macroeconomic volatility to real and monetary shocks. We explore two channels through which financial development and output volatility may be linked. These channels are discussed broadly in the literature as follows. Gavin and Hausmann (1996) show that external terms-of-trade (TOT) shocks are associated with increased growth volatility, while Singer and Edström (1993) and Lutz (1994) find that greater TOT volatility reduces growth. Bleaney and Fielding (2002) show that there is a tradeoff in the choice of exchange rate regime between inflation volatility and stability of output.

Conrad et al. (2010) demonstrate that the relationship between output volatility and inflation volatility is positive, and that the central bank's commitment to reducing inflation volatility helps decrease output volatility. However, the relationship between output and inflation is not that simple: it varies, depending on the type of shock to the economy. In the model developed by Cecchetti et al. (2002), the ratio between inflation and output volatility depends on the slope of the supply curve. Thus, a country that has a relatively high aversion toward inflation variability would suffer more in terms of output volatility.

Introducing these two channels, we estimate the following model:

$$
\begin{aligned}
\text { OV }= & \alpha_{1}(l G D P)_{i, t}+\alpha_{2} S D(T O T)_{i, t}+\alpha_{3} S D(I N F)_{i, t}+\beta_{1}(F D)_{i, t}+ \\
& \delta(X)_{i, t}+\mu_{i}+\varepsilon_{i, t}
\end{aligned}
$$

The following four regressions are estimated for four distinct measures of financial development:

$$
\begin{aligned}
\text { OV }= & \alpha_{1}(\text { lGDP })_{i, t}+\alpha_{2} S D(\text { TOT })_{i, t}+\alpha_{3} S D(\text { INF })_{i, t}+\beta_{1}(P C)_{i, t}+ \\
& \delta(X)_{i, t}+\mu_{i}+\varepsilon_{i, t} \\
O V= & \alpha_{1}(\text { lGDP })_{i, t}+\alpha_{2} S D(T O T)_{i, t}+\alpha_{3} S D(I N F)_{i, t}+\beta_{1}(N I M)_{i, t}+ \\
& \delta(X)_{i, t}+\mu_{i}+\varepsilon_{i, t} \\
O V= & \alpha_{1}(\text { lGDP })_{i, t}+\alpha_{2} S D(T O T)_{i, t}+\alpha_{3} S D(I N F)_{i, t}+\beta_{1}(Z S)_{i, t}+ \\
& \delta(X)_{i, t}+\mu_{i}+\varepsilon_{i, t}
\end{aligned}
$$




$$
\begin{aligned}
\text { OV }= & \alpha_{1}(l G D P)_{i, t}+\alpha_{2} S D(T O T)_{i, t}+\alpha_{3} S D(I N F)_{i, t}+\beta_{1}(B B)_{i, t}+ \\
& \delta(X)_{i, t}+\mu_{i}+\varepsilon_{i, t}
\end{aligned}
$$

where $S D(T O T)$ is the four-year SD of TOT as a measure of real sector shocks and $S D(I N F)$ is the four-year SD of inflation as a measure of monetary shocks. $P C$ is the ratio of private credit to GDP (the financial resources provided to the private sector by domestic money banks) and is used to measure financial depth. NIM is the net interest margin (the accounting value of a bank's net interest revenue as a share of its average interestbearing or total earning assets), measuring financial efficiency. ZS is the bank's z-score (the probability of default of a country's banking system) and measures financial stability. $B B$ is the number of bank branches per 100,000 adults and is used to measure financial access.

Despite substantial evidence concerning the role of the financial system in shaping economic development, there are serious shortcomings associated with measuring how this system functions. The literature does not provide sound cross-country, cross-period measures of the degree to which financial systems enhance the quality of information about firms and hence the efficiency of resource allocation, or impose good corporate governance on the firms to which they funnel those resources. Nor are there any measures to indicate whether financial systems provide effective mechanisms to manage, pool and diversify risk; to mobilize savings from disparate savers so that these resources can be allocated to the most promising projects in the economy; or to facilitate trade. Instead, researchers have largely (though not exclusively) relied on measures of the size of the banking industry as a proxy. However, size is not a measure of quality, efficiency or stability. We have therefore used four measures of financial development to obtain a comprehensive picture of the financial sector's role in determining output volatility.

Finally, we also incorporate interaction terms involving financial development and the SD of TOT and that of inflation, as applied by DablaNorris and Srivisal (2013) and Beck et al. (2000). We estimate the following regression equation with interaction terms:

$$
\begin{aligned}
O V= & \alpha_{1}(\text { lGDP })_{i, t}+\alpha_{2} S D(T O T)_{i, t}+\alpha_{3} S D(I N F)_{i, t}+\beta_{1}(F D)_{i, t}+ \\
& \gamma_{1}(F D * S D T O T)_{i, t}+\gamma_{2}(F D * S D I N F)_{i, t}+\delta(X)_{i, t}+\mu_{i}+\varepsilon_{i, t}
\end{aligned}
$$

The following four models are estimated for four distinct measures of financial development with interaction terms: 


$$
\begin{aligned}
& O V=\alpha_{11}(\text { lGDP })_{i, t}+\alpha_{12}(v T O T)_{i, t}+\alpha_{13}(v I N F)_{i, t}+\beta_{11}(P C)_{i, t}+ \\
& \gamma_{1}(P C * v T O T)_{i, t}+\gamma_{2} P C v I N F_{i, t}+\delta l O P E N_{i, t}+\mu_{i}+\varepsilon_{i, t} \\
& O V=\alpha_{21}(l G D P)_{i, t}+\alpha_{22}(v T O T)_{i, t}+\alpha_{23}(v I N F)_{i, t}+\beta_{21}(N I M)_{i, t}+ \\
& \gamma_{1}\left(\text { NIMvTOT }_{i, t}+\gamma_{2} \text { NIMvINF }_{i, t}+\delta l O P E N_{i, t}+\mu_{i}+\varepsilon_{i, t} \quad\right. \text { (3.2) } \\
& O V=\alpha_{31}(l G D P)_{i, t}+\alpha_{32}(v T O T)_{i, t}+\alpha_{33}(v I N F)_{i, t}+\beta_{31}(Z S)_{i, t}+ \\
& \gamma_{1}(Z S v T O T)_{i, t}+\gamma_{2} Z_{\text {SvINF }} i, t+\delta \text { IOPEN }_{i, t}+\mu_{i}+\varepsilon_{i, t} \\
& O V=\alpha_{41}(l G D P)_{i, t}+\alpha_{42}(v T O T)_{i, t}+\alpha_{43}(v I N F)_{i, t}+\beta_{41}(B B)_{i, t}+ \\
& \gamma_{1}(B B v T O T)_{i, t}+\gamma_{2} B_{B V I N F_{i, t}}+\delta \operatorname{lOPEN}_{i, t}+\mu_{i}+\varepsilon_{i, t}
\end{aligned}
$$

where $S D(T O T)$ is labelled $v T O T, S D(I N F)$ is labelled $v I N F$, and $\gamma_{1}$ and $\gamma_{2}$ are the coefficients of the interaction terms for financial development with the $\mathrm{SD}$ of TOT and the SD of inflation, respectively. A negative (positive) sign on $\gamma_{1}$ would indicate that the development of financial intermediaries reduces (magnifies) the incidence of real volatility. A negative (positive) sign on $\gamma_{2}$ would imply that financial intermediaries dampen (aggravate) the incidence of monetary volatility.

\subsection{Econometric Techniques}

Our analysis spans 79 countries over the period 1961-2012, based on data from the World Development Indicators and International Financial Statistics. ${ }^{1}$ We employ dynamic panel data, as the data for GDP per capita depends on its previous values. This enables us not only to control for unobserved cross-country heterogeneity, but also to investigate dynamic relationships.

To examine the relationship between financial development and economic growth, we use the generalized method of moments (GMM) estimators developed for dynamic panel models by Arellano and Bond (1991). Greene (1997) points out that GMM yields consistent and efficient estimates in the presence of arbitrary heteroskedasticity, while Arellano and Bond show that the error term $\varepsilon$ is not serially correlated and that the independent variables $X$ are weakly exogenous. With these conditions in mind, they propose a two-step GMM estimator. First, the error terms are assumed to be independent and homoskedastic across countries and over time. Second, the residuals retained in the first step are used to construct a

1 See http://data.worldbank.org/data-catalog/world-development-indicators for the World Development Indicators and http://www.imf.org/en/Data for the International Financial Statistics. 
consistent estimate of the variance-covariance matrix, thereby relaxing the assumptions of independence and homoskedasticity.

\subsection{Descriptive Analysis}

As Table 1 shows, the minimum value of output volatility is 1.76 for Australia and the maximum value is 10.09 for Rwanda. The minimum value of financial depth (private credit to GDP) is 5.47 for Rwanda and the maximum value is 136.58 for the UK. The minimum value of financial stability (z-score) is -1.40 and the maximum value is 43.08 , for Ecuador and Panama, respectively. The minimum value of financial efficiency (the net interest margin) is 0.706 and the maximum value is 12.19 , for Ireland and Ghana, respectively. The minimum value of financial access (number of bank branches) is 1.19 and the maximum value is 112.80, for Argentina and Cyprus, respectively. The minimum value of inflation volatility is 1.13 and the maximum value is 58.24, for Germany and Uruguay, respectively. Finally, the minimum value of TOT volatility is 2.26 and the maximum value is 118.48, for Belgium and Iran, respectively.

Table 1: Descriptive statistics

\begin{tabular}{lcccc}
\hline Variable & Mean & SD & Min & Max \\
\hline Output volatility & 4.053454 & 1.827282 & 1.762503 & 10.09317 \\
Growth & 8.139591 & 1.655917 & 5.026165 & 10.72645 \\
SD (INF) & 4.257263 & 5.933262 & 1.129389 & 58.24967 \\
SD (TOT) & 17.15693 & 18.2415 & 2.259562 & 118.4770 \\
Private credit to GDP & 41.31117 & 31.72726 & 5.466166 & 136.5836 \\
Bank deposits & 49.35951 & 35.35775 & 6.907424 & 163.3433 \\
Net interest margin & 4.094926 & 2.588214 & 0.706318 & 12.18597 \\
Overhead cost & 3.487886 & 2.409974 & 0.3492328 & 12.86581 \\
Z-score & 16.26136 & 10.54338 & -1.40414 & 43.07984 \\
Bank branches & 21.63507 & 22.91749 & 1.195648 & 112.8031 \\
Openness & 4.030614 & 0.5496448 & 2.827155 & 5.791479 \\
\hline
\end{tabular}

Source: Authors' calculations

Table 2 shows the correlation among the variables used in the study. Output volatility is positively correlated with volatility in inflation and TOT changes. It is negatively correlated with three financial development indicators - the ratio of private credit to GDP, z-scores and the number of bank branches per 100,000 adults - and positively correlated with net interest margin (financial efficiency). GDP per capita growth is negatively correlated with output volatility, while openness is positively correlated with output volatility. 
Table 2: Correlation matrix

\begin{tabular}{lccccccccc}
\hline Variable & OV & LGDP & $\begin{array}{c}\text { SD } \\
\text { (INF) }\end{array}$ & $\begin{array}{c}\text { SD } \\
\text { (TOT) }\end{array}$ & PC & NIM & ZS & BB & $\begin{array}{c}\text { LOPE } \\
\text { N }\end{array}$ \\
\hline Output volatility & 1.0000 & & & & & & & & \\
Growth & -0.4063 & 1.0000 & & & & & & & \\
SD (INF) & 0.0134 & 0.0927 & 1.0000 & & & & & & \\
SD (TOT) & 0.2204 & 0.2228 & 0.0689 & 1.0000 & & & & & \\
Private credit to GDP & -0.3320 & 0.7154 & 0.1278 & 0.1567 & 1.0000 & & & & \\
Net interest margin & 0.3324 & 0.6612 & 0.0999 & 0.2390 & 0.6922 & 1.0000 & & & \\
Z-score & -0.0713 & 0.0246 & 0.0797 & 0.2610 & 0.0422 & 0.0627 & 1.0000 & & \\
Bank branches & -0.2498 & 0.6436 & 0.0584 & 0.1120 & 0.6306 & 0.4661 & 0.0645 & 1.0000 & \\
Openness & 0.0253 & 0.3573 & 0.0748 & 0.1148 & 0.2147 & 0.1685 & 0.1823 & 0.2252 & 1.0000 \\
\hline
\end{tabular}

Source: Authors' calculations

\section{Estimations and Results}

This section presents the study's estimation results.

\subsection{Cross-Country OLS Regression Results}

Table 3 gives the estimation results for the ordinary least squares (OLS) regression equations given in Section 3, as equations 2.1 to 2.4. These results show that private credit to GDP (column 1) and z-score (column 3) have negative signs, indicating that an increase in financial depth and financial stability leads to a decrease in output fluctuations. This implies that well-developed financial systems can dampen output volatility by removing or alleviating financial constraints. These finding are in line with Bernanke and Gertler (1989), Kiyotaki and Moore (1997), and Wurgler (2000).

Aghion et al. (1999) build a macroeconomic model with microfoundations, which predicts that less developed financial systems, where credit to the private sector is low, tend to be more volatile. They show that low financial development separates savers from investors, resulting in macroeconomic fluctuations, with the economy converging on a cycle around its steady-state growth path. In contrast, in the presence of financial development, where credit to the private sector is high, the economy converges on a stable growth path along which fluctuations occur due only to exogenous shocks. The authors conclude that, 'when the financial sector is not as well developed, the supply of and the demand for credit is more cyclical.' Thus, 'investors are more likely to get locked out of credit markets when the economy faces a bad shock, only to rush back in when the economy sustains a good shock.' 
Table 3: Cross-sectional OLS regression of output volatility for measures of financial development

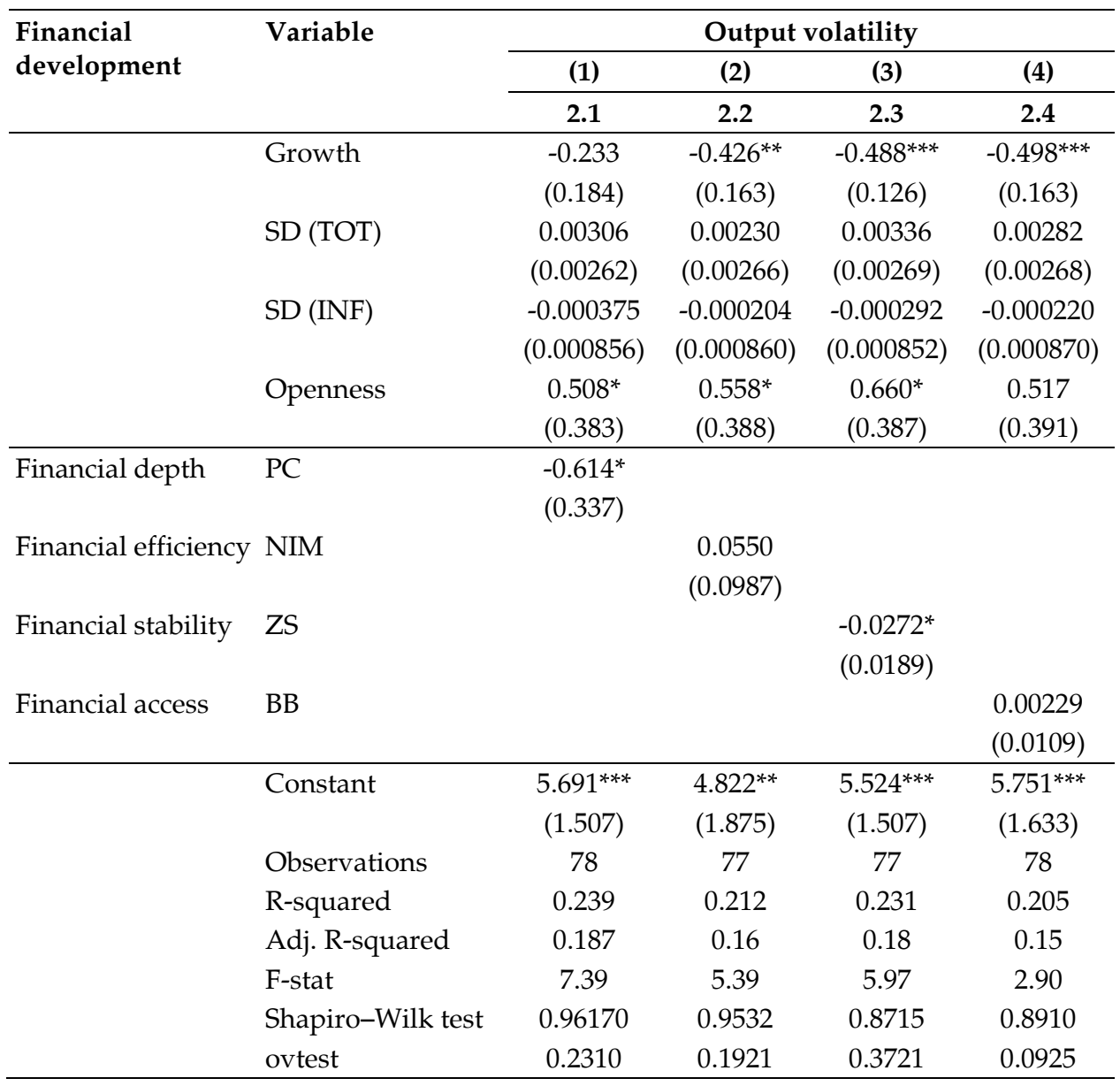

Note: Standard errors in parentheses. ${ }^{* * *} p<0.01,{ }^{* *} p<0.05, * p<0.1$.

$\mathrm{BB}=$ bank branches, $\mathrm{INF}=$ inflation, $\mathrm{NIM}=$ net interest margin, $\mathrm{PC}=$ private credit to GDP, TOT $=$ terms of trade, $\mathrm{ZS}=\mathrm{z}$-score.

Source: Authors' calculations

The coefficients of net interest margin (column 2) and the number of bank branches per 100,000 adults (column 4) are positive, showing that greater financial access and financial efficiency increase output fluctuations, as found by Popov (2011) and Acemoglu et al. (2003). These findings suggest that financial development plays a mixed role in output volatility, supporting Beck et al. (2006), who conclude that no robust relationship exists between financial development and aggregate economic volatility. The Shapiro-Wilk test statistic and ovtest confirm the normality and functional form of the model. 
We find that, as growth increases, output volatility decreases: this result is significant and the signs are correct in all the regressions. When the growth rate of a country increases, this helps stabilize different sectors of the economy and lower the overall output volatility. Since the sources of real and monetary volatility affect producers and intermediaries, we use the SD of TOT changes, $S D$ (TOT), as a proxy for the extent to which an economy is exposed to real sector shocks, and the SD of the inflation rate, $S D(I N F)$, as a proxy for the extent to which an economy is exposed to monetary shocks. $S D(I N F)$ has a negative sign, showing that disturbances or destabilization in the monetary sector do not increase growth volatility. $S D(T O T)$ has a positive sign, showing that disturbances or destabilization in the real sector increase output volatility. The signs of the real sector volatility variable are correct and significant. The openness variable has a positive sign in all the regressions, implying that greater openness leads to higher output volatility: economies that are more open are also more vulnerable to global shocks.

The literature on openness and volatility indicates that greater openness can have positive and negative output volatility consequences. For example, Haddad et al. (2013) observe that, 'despite an extensive existing literature on the subject, there is no clear consensus to date whether greater openness comes at the cost of a more volatile growth path.' They argue that, on the one hand, greater openness causes more volatility because an economy that relies on trade to drive economic activity is more exposed to external shocks and thus more volatile. On the other hand, greater openness also reduces volatility because increasing access to international markets protects the economy against significant growth slowdowns due to domestic demand shortages, thereby reducing volatility. Our results are consistent with Kose et al. (2006), who argue that 'openness increases vulnerability to external shocks.' They also observe that 'most studies find that an increase in the degree of trade openness leads to higher output volatility.'

\subsection{Cross-Sectional Results with Interaction Terms}

Incorporating the interaction terms yields equations 3.1-3.4 (Section 3). Table 4 incorporates two sets of interaction terms, combining financial development with monetary sector volatility and real sector volatility in each regression line. The results in columns 1 and 4 show that the coefficients of private credit to GDP and the number of bank branches per 100,000 adults are positive, which means that an increase in financial depth and financial access increases output volatility. These coefficients are very small and insignificant. Private credit to GDP measures the size of the financial sector: as this sector grows, it attracts greater resources, allowing riskier investments, which can increase output volatility. 
Table 4: Cross-sectional OLS regression results with interaction terms

\begin{tabular}{|c|c|c|c|c|c|}
\hline \multirow{8}{*}{$\begin{array}{l}\text { Financial } \\
\text { development }\end{array}$} & \multirow[t]{3}{*}{ Variable } & \multicolumn{4}{|c|}{ Output volatility } \\
\hline & & (1) & $(2)$ & (3) & (4) \\
\hline & & 3.1 & 3.2 & 3.3 & 3.4 \\
\hline & Growth & $\begin{array}{c}-0.396^{* *} \\
(0.177)\end{array}$ & $\begin{array}{c}-0.474^{* * *} \\
(0.167)\end{array}$ & $\begin{array}{c}-0.459^{* * *} \\
(0.131)\end{array}$ & $\begin{array}{c}-0.504^{* * *} \\
(0.165)\end{array}$ \\
\hline & $\mathrm{SD}(\mathrm{TOT})$ & $\begin{array}{c}0.0115^{*} \\
(0.00614)\end{array}$ & $\begin{array}{l}-0.00434 \\
(0.00576)\end{array}$ & $\begin{array}{c}0.00933^{*} \\
(0.00603)\end{array}$ & $\begin{array}{c}0.00295 \\
(0.00527)\end{array}$ \\
\hline & $\mathrm{SD}(\mathrm{INF})$ & 0.000217 & -0.00320 & -0.00367 & -0.00107 \\
\hline & & (0.00366) & $(0.00653)$ & $(0.0141)$ & (0.00153) \\
\hline & Openness & $\begin{array}{c}0.740^{*} \\
(0.413)\end{array}$ & $\begin{array}{c}0.645^{*} \\
(0.395)\end{array}$ & $\begin{array}{c}0.683^{*} \\
(0.391)\end{array}$ & $\begin{array}{l}0.559^{*} \\
(0.404)\end{array}$ \\
\hline \multirow[t]{3}{*}{ Financial depth } & PC & $\begin{array}{l}0.00601 \\
(0.0110)\end{array}$ & & & \\
\hline & PC-SD (TOT) & $\begin{array}{l}-0.000220^{*} \\
(0.000136)\end{array}$ & & & \\
\hline & PC-SD (INF) & $\begin{array}{l}-0.000304 \\
(0.000176)\end{array}$ & & & \\
\hline \multirow[t]{3}{*}{ Financial efficiency } & NIM & & $\begin{array}{c}-0.0781 \\
(0.140)\end{array}$ & & \\
\hline & NIM-SD (TOT) & & $\begin{array}{l}0.00144^{*} \\
(0.00115)\end{array}$ & & \\
\hline & NIM-SD (INF) & & $\begin{array}{l}0.000553 \\
(0.00120)\end{array}$ & & \\
\hline \multirow[t]{3}{*}{ Financial stability } & $\mathrm{ZS}$ & & & $\begin{array}{l}-0.0120 \\
(0.0284)\end{array}$ & \\
\hline & ZS-SD (TOT) & & & $\begin{array}{l}-0.000201^{*} \\
(0.000179)\end{array}$ & \\
\hline & ZS-SD (INF) & & & $\begin{array}{l}0.000290 \\
(0.00124)\end{array}$ & \\
\hline \multirow[t]{9}{*}{ Financial access } & $\mathrm{BB}$ & & & & $\begin{array}{l}0.00300 \\
(0.0169)\end{array}$ \\
\hline & BB-SD (TOT) & & & & $\begin{array}{c}-0.0000266 \\
(0.000245)\end{array}$ \\
\hline & BB-SD (INF) & & & & $\begin{array}{c}0.0000679 \\
(0.0000991 \\
)\end{array}$ \\
\hline & Constant & $\begin{array}{l}3.786^{* *} \\
(1.859)\end{array}$ & $\begin{array}{c}5.391^{* * *} \\
(1.922)\end{array}$ & $\begin{array}{l}4.786^{* * *} \\
(1.657)\end{array}$ & $\begin{array}{c}5.637^{* * *} \\
(1.768)\end{array}$ \\
\hline & Observations & 78 & 77 & 77 & 78 \\
\hline & R-squared & 0.240 & 0.233 & 0.247 & 0.210 \\
\hline & F-stat & 4.31 & 4.22 & 4.49 & 2.18 \\
\hline & Shapiro-Wilk test & 0.9001 & 0.9732 & 0.7501 & 0.8920 \\
\hline & ovtest & 0.2010 & 0.1561 & 0.0321 & 0.5306 \\
\hline
\end{tabular}

Note: Standard errors in parentheses. ${ }^{* * *} p<0.01,{ }^{* *} p<0.05, * p<0.1$.

$\mathrm{BB}=$ bank branches, INF = inflation, $\mathrm{NIM}=$ net interest margin, $\mathrm{PC}=$ private credit to GDP, TOT $=$ terms of trade, $\mathrm{ZS}=\mathrm{z}$-score.

Source: Authors' calculations 
An important determinant of the magnitude of the financial sector is the extent of integration with global capital markets. Weaknesses in the country's own financial institutions will matter less if firms have easy access to banks abroad. While greater financial depth could, in principle, serve to smooth the country's adjustment to a shock, it could also increase exposure to adverse sources of dynamic reaction and increase output volatility. The coefficients of net interest margin (financial efficiency) and z-score (financial stability) are negative, which means that financial efficiency and financial stability help decrease output volatility. However, this evidence is weak and insignificant.

The coefficients of $S D(T O T)$ are positive in columns 1, 3 and 4 as expected: the more the economy is exposed to real shocks, the higher will be its output volatility. The results suggest that TOT and inflation volatility have a small impact on output volatility. The SD of TOT changes is positive and significant at 1 percent in column 1 . The coefficients of SD(INF) are negative in columns 2-4, contradictory to our expectations: the more an economy is exposed to monetary shocks, the lower will be its output volatility. The results suggest that TOT and inflation volatility have a small effect on output volatility.

The interaction terms involving real sector volatility and financial efficiency, stability and access have negative signs in columns 1, 3 and 4, respectively. These results provide weak evidence for the dampening effect of financial intermediary development on TOT volatility. Overall, we find only weak evidence to show that the impact of TOT volatility falls in the presence of well-developed financial intermediaries. On the other hand, the positive signs of the interaction term incorporating monetary volatility in columns 2-4 provides weak evidence for the magnifying effect of financial development on monetary volatility. The results suggest that the impact of inflation volatility on output volatility increases in the presence of welldeveloped financial intermediaries. The Shapiro-Wilk test statistic and ovtest confirm the normality and functional form of the model.

\subsection{Two-Stage Least Squares Results for Cross-Sectional Data}

This section presents our empirical results, using 2SLS to overcome the limitations of OLS, which does not address the problem of endogeneity. To use OLS, we must be able to meet the zero-conditional-mean assumption. This assumption is violated in three instances: endogeneity (defined as the simultaneous determination of explanatory variables and the explained variable), omitted variable bias and the measurement error in the 
explanatory variables. These problems arise for different reasons, but have a common solution: the use of instrumental variables (IVs).

Tables 5 and 6 give the 2SLS results, with legal origin, capital account openness and initial values used as instruments. The R-squared values increase significantly compared to the OLS results. Financial efficiency (net interest margin) and financial stability (z-score) are negative and significant at the 1 percent level of significance, while financial depth (private credit to GDP) and financial access (number of bank branches per 100,000 adults) contribute positively to increasing output volatility. Barring net interest margin, all other measures of financial development contribute significantly to reducing the volatility of the real sector, but the magnitude of this impact is small. The volatility of the monetary sector is also reduced by all financial development indictors except net interest margin.

Table 5: First-stage least squares results

\begin{tabular}{|c|c|c|c|c|}
\hline Variable & PC & NIM & ZS & BB \\
\hline Initial PC & $\begin{array}{c}0.5154642^{* * *} \\
(0.000)\end{array}$ & & & \\
\hline Initial NIM & & $\begin{array}{c}0.0407427 \\
(0.478)\end{array}$ & & \\
\hline Initial ZS & & & $\begin{array}{c}-0.0586756 \\
(0.501)\end{array}$ & \\
\hline Initial BB & & & & $\begin{array}{c}-0.0155664 \\
(0.789)\end{array}$ \\
\hline English & $\begin{array}{c}19.10035 \\
(0.156)\end{array}$ & $\begin{array}{c}-1.031573 \\
(0.486)\end{array}$ & $\begin{array}{c}-4.294696 \\
(0.556)\end{array}$ & $\begin{array}{c}4.531393 \\
(0.707)\end{array}$ \\
\hline Socialist & $\begin{array}{c}34.6761^{* * *} \\
(0.039)\end{array}$ & $\begin{array}{c}-2.59425 \\
(0.151)\end{array}$ & $\begin{array}{c}-4.647148 \\
(0.597)\end{array}$ & $\begin{array}{c}-2.940262 \\
(0.838)\end{array}$ \\
\hline French & $\begin{array}{c}12.28926 \\
(0.356)\end{array}$ & $\begin{array}{l}-1.2737 \\
(0.387)\end{array}$ & $\begin{array}{c}-2.278271 \\
(0.753)\end{array}$ & $\begin{array}{c}2.911096 \\
(0.807)\end{array}$ \\
\hline German & $\begin{array}{c}38.30772^{* * *} \\
(0.015)\end{array}$ & $\begin{array}{c}-1.714287 \\
(0.302)\end{array}$ & $\begin{array}{c}-1.14229 \\
(0.889)\end{array}$ & $\begin{array}{c}-7.883624 \\
(0.562)\end{array}$ \\
\hline Scandan & $\begin{array}{c}10.81364 \\
(0.458)\end{array}$ & $\begin{array}{c}-1.683834 \\
(0.308)\end{array}$ & $\begin{array}{c}1.867108 \\
(0.819)\end{array}$ & $\begin{array}{c}-11.77449 \\
(0.385)\end{array}$ \\
\hline _Cons & $\begin{array}{c}-26.87766 \\
(0.196) \\
\end{array}$ & $\begin{array}{c}8.728035^{* * *} \\
(0.000) \\
\end{array}$ & $\begin{array}{c}18.25015^{*} \\
(0.073)\end{array}$ & $\begin{array}{c}12.00845 \\
(0.499) \\
\end{array}$ \\
\hline Observations & 77 & 73 & 74 & 69 \\
\hline R-squared & 0.8599 & 0.7601 & 0.6089 & 0.7912 \\
\hline Adj. R-squared & 0.84 & 0.74 & 0.59 & 0.76 \\
\hline F-stat & 32.74 & 15.84 & 7.92 & 17.68 \\
\hline Sargan's test & $(0.6952)$ & $(0.6011)$ & $(0.6689)$ & $(0.4311)$ \\
\hline
\end{tabular}

Note: $\mathrm{BB}=$ bank branches, $\mathrm{NIM}=$ net interest margin, $\mathrm{PC}=$ private credit to GDP, $\mathrm{ZS}=\mathrm{z}$-score. Source: Authors' calculations 
Table 6: Second-stage least squares results

\begin{tabular}{|c|c|c|c|c|c|}
\hline \multirow{2}{*}{$\begin{array}{l}\text { Financial } \\
\text { development }\end{array}$} & \multirow[t]{2}{*}{ Variable } & \multicolumn{4}{|c|}{ Output volatility } \\
\hline & & (1) & (2) & (3) & (4) \\
\hline & \multirow[t]{2}{*}{ Growth } & -0.0911 & $-0.140^{* *}$ & $-0.119^{*}$ & -0.0188 \\
\hline & & $(0.0601)$ & $(0.0626)$ & $(0.0607)$ & $(0.0667)$ \\
\hline & \multirow[t]{2}{*}{$\mathrm{SD}$ (TOT) } & $0.0986^{* * *}$ & 0.0129 & $0.0778^{* *}$ & $0.108^{* * *}$ \\
\hline & & $(0.00742)$ & $(0.0148)$ & $(0.0349)$ & $(0.00847)$ \\
\hline & \multirow[t]{2}{*}{$\mathrm{SD}$ (INF) } & $0.0133^{*}$ & $-0.0569^{* * *}$ & $0.0892^{* * *}$ & -0.000673 \\
\hline & & $(0.00729)$ & $(0.0127)$ & $(0.0270)$ & (0.00542) \\
\hline & \multirow[t]{2}{*}{ Openness } & -0.0297 & -0.0494 & -0.138 & 0.0744 \\
\hline & & $(0.156)$ & $(0.154)$ & $(0.167)$ & $(0.158)$ \\
\hline \multirow[t]{6}{*}{ Financial depth } & \multirow[t]{2}{*}{ PC } & $0.0430^{* * *}$ & & & \\
\hline & & $(0.00811)$ & & & \\
\hline & \multirow[t]{2}{*}{ PC-SD (TOT) } & $-0.000753^{* * *}$ & & & \\
\hline & & $(0.000180)$ & & & \\
\hline & \multirow[t]{2}{*}{ PC-SD (INF) } & $-0.000634^{* * *}$ & & & \\
\hline & & $(0.000187)$ & & & \\
\hline \multirow{6}{*}{$\begin{array}{l}\text { Financial } \\
\text { efficiency }\end{array}$} & \multirow[t]{2}{*}{ NIM } & & $-0.759 * * *$ & & \\
\hline & & & $(0.162)$ & & \\
\hline & \multirow[t]{2}{*}{ NIM-SD (TOT) } & & $0.0113^{* * *}$ & & \\
\hline & & & $(0.00289)$ & & \\
\hline & \multirow{2}{*}{ NIM-SD (INF) } & & $0.0114^{* * *}$ & & \\
\hline & & & $(0.00290)$ & & \\
\hline \multirow[t]{6}{*}{ Financial stability } & \multirow[t]{2}{*}{ ZS } & & & $-0.479^{* * *}$ & \\
\hline & & & & $(0.176)$ & \\
\hline & \multirow[t]{2}{*}{ ZS-SD (TOT) } & & & -0.00263 & \\
\hline & & & & $(0.00246)$ & \\
\hline & \multirow[t]{2}{*}{ ZS-SD (INF) } & & & $-0.00337^{* *}$ & \\
\hline & & & & $(0.00147)$ & \\
\hline \multirow[t]{18}{*}{ Financial access } & \multirow[t]{2}{*}{ BB } & & & & $0.0890^{* * *}$ \\
\hline & & & & & $(0.0292)$ \\
\hline & \multirow[t]{2}{*}{ BB-SD (TOT) } & & & & $-0.00218^{* * *}$ \\
\hline & & & & & $(0.000409)$ \\
\hline & \multirow{2}{*}{ BB-SD (INF) } & & & & -0.000219 \\
\hline & & & & & $(0.000240)$ \\
\hline & Constant & $-1.349^{*}$ & $4.424^{* * *}$ & $10.03^{* * *}$ & $-2.185^{* *}$ \\
\hline & & $(0.754)$ & $(0.995)$ & (2.735) & $(0.834)$ \\
\hline & Observations & 78 & 78 & 78 & 78 \\
\hline & R-squared & 0.884 & 0.886 & 0.196 & 0.885 \\
\hline & Adj. R-squared & 0.861 & 0.861 & 0.180 & 0.861 \\
\hline & $\mathrm{Wu}-$ Hausman & 0.6093 & 0.5342 & 0.6661 & 0.3211 \\
\hline & Cragg-Donald test & 55.44 & 7.42 & 41.33 & 85.01 \\
\hline & & $(0.000)$ & $(0.000)$ & $(0.000)$ & $(0.000$ \\
\hline & Cumby-Huizinga & 105.489 & 105.151 & 105.002 & 105.311 \\
\hline & test & $(0.000)$ & $(0.000)$ & $(0.000)$ & $(0.000)$ \\
\hline & J-statistic & 5.71 & 6.64 & 4.57 & 4.49 \\
\hline & & 0.33 & 0.24 & 0.47 & 0.48 \\
\hline
\end{tabular}

Note: $\mathrm{BB}=$ bank branches, $\mathrm{INF}=$ inflation, $\mathrm{NIM}=$ net interest margin, $\mathrm{PC}=$ private credit to GDP, TOT = terms of trade, $\mathrm{ZS}=\mathrm{z}$-score.

Source: Authors' calculations 
We have also examined endogeneity for the inclusion of GDP and its variation in the same model, using the Wu-Hausman test, the null hypothesis of which is that the variable under consideration can be treated as exogenous. Here, the test statistics are highly insignificant across all the models, so we cannot reject the null hypothesis of exogeneity. Accordingly, we continue to treat GDP and its variations as exogenous.

\subsection{Pooled OLS Results}

Table 7 gives the results of the pooled OLS regressions. The negative signs of private credit to GDP, the z-score and number of bank branches show that better financial development helps decrease output volatility. Private credit allows smoother consumption by relieving household liquidity constraints. In turn, smaller fluctuations in real consumption expenditure reduce the volatility of output growth. This indicator has been used in many studies, including Levine and Zervos (1998) and Beck et al. (2000).

Financial intermediaries and markets lower the cost of assessing investments and projects, managing risks and mobilizing savings. All the measures of financial development are significant, although their magnitudes are small. Private credit to GDP and the z-score are significant at 5 percent, while net interest margin and the number of bank branches are significant at 1 percent. When financial depth increases by 1 percent, this causes output volatility to fall by 0.6 percent. An increase in financial efficiency of 1 percent will decrease output fluctuations by 5 percent. When financial stability increases by 1 percent, output volatility falls by 1 percent and an increase in financial access decreases output volatility by 0.9 percent. 
Table 7: Pooled OLS results without interaction terms

\begin{tabular}{llcccc}
\hline Financial & Variable & \multicolumn{4}{c}{ Output volatility } \\
\cline { 3 - 5 } development & & $\mathbf{( 1 )}$ & $\mathbf{( 2 )}$ & $\mathbf{( 3 )}$ & $\mathbf{( 4 )}$ \\
\hline & Growth & $-0.179^{*}$ & -0.0590 & $-0.121^{* *}$ & -0.0176 \\
& & $(0.0917)$ & $(0.0750)$ & $(0.0607)$ & $(0.0967)$ \\
& SD (TOT) & $0.00485^{*}$ & $0.00623^{* *}$ & $0.00677^{* *}$ & $0.00493^{*}$ \\
& & $(0.00380)$ & $(0.00281)$ & $(0.00280)$ & $(0.00312)$ \\
& SD (INF) & 0.000253 & $0.0676^{* *}$ & $0.0614^{*}$ & 0.0410 \\
& & $(0.000355)$ & $(0.0317)$ & $(0.0317)$ & $(0.0482)$ \\
& Openness & 0.192 & $0.603^{* * *}$ & $0.685^{* * *}$ & $0.635^{* * *}$ \\
& & $(0.208)$ & $(0.193)$ & $(0.195)$ & $(0.244)$ \\
\hline Depthiciency & PC & $-0.00661^{* *}$ & & & \\
& & $(0.00330)$ & & & \\
Stability & NIM & & $0.0502^{*}$ & & \\
& & & $(0.0428)$ & & \\
& ZS & & & $-0.0169^{* *}$ & \\
& & & & $(0.00846)$ & \\
& BB & & & & $-0.00919^{*}$ \\
& Constant & $3.513^{* * *}$ & -0.408 & 0.246 & -0.377 \\
& & $(0.909)$ & $(0.987)$ & $(0.842)$ & $(1.162)$ \\
& Observations & 523 & 302 & 303 & 202 \\
& R-squared & 0.053 & 0.083 & 0.091 & 0.069 \\
& VIF & 4.18 & 2.93 & 2.17 & 2.32 \\
& Skewness test & 0.0021 & 0.0000 & 0.0100 & 0.2781 \\
& Wald test & 0.0000 & 0.0000 & 0.0000 & 0.0000 \\
& linktest & 0.2577 & 0.1106 & 0.1328 & 0.9677 \\
& ovtest & 0.691 & 0.305 & 0.420 & 0.791 \\
& Wooldridge's test & 0.603 & 0.065 & 0.285 & 0.000 \\
\hline
\end{tabular}

Note: Standard errors in parentheses. ${ }^{* *} p<0.01,{ }^{* *} p<0.05, * p<0.1$.

$\mathrm{BB}=$ bank branches, INF = inflation, $\mathrm{NIM}=$ net interest margin, $\mathrm{PC}=$ private credit to GDP, TOT $=$ terms of trade, $\mathrm{ZS}=\mathrm{z}$-score.

Source: Authors' calculations

The results also show that a 1 percent increase in monetary sector volatility raises output volatility from 0.02 percent (column 1) to 7 percent (column 2). As expected, and as Beck et al. (2006) find, SD(TOT) has a positive sign, showing that disturbances or destabilization in the real sector will increase output volatility. The results show that a 1 percent increase in real sector volatility raises output volatility from 0.4 percent (column 1 ) to 0.7 percent (column 3). The coefficient of trade openness has a positive sign in all the regressions, implying that greater openness increases output volatility. An open economy is more exposed to external (global) shocks, thereby increasing its overall output volatility. 
The linktest and ovtest results gauge the functional form of the models, based on the idea that, if a regression or regression-like equation is specified correctly, the models are too. The problem of multicollinearity does not arise, as the VIF is less than 10 for all the models. We use the modified Wald test to determine heteroskedasticity, which is resolved by using robust regressions. Since serial correlation in linear panel data models can lead to bias in the standard errors, yielding less efficient results, we apply Wooldridge's test ( $\mathrm{H} 0=$ no first-order autocorrelation, if $p>0.1$ accept $\mathrm{H} 0)$. The results indicate no first-order autocorrelation in models 1 and 3, and weak evidence of first-order autocorrelation in models 2 and 4 .

\subsection{Pooled OLS Results with Interaction Terms}

Table 8 gives the results of the pooled OLS regressions including the interaction terms combining financial development with monetary sector volatility and real sector volatility. The results show that a 1 percent increase in monetary sector volatility will raise output volatility from 0.1 percent (column 1) to 9 percent (column 2). The signs of real sector volatility are correct and significant. The SD of TOT changes is positive in all OLS regressions. The results show that a 1 percent increase in real sector volatility will increase output volatility from 0.3 percent (column 1) to 0.9 percent (column 3). The negative signs of private credit to GDP, z-score and bank branches show that better financial development helps decrease output volatility, which is consistent with Denizer et al. (2002) and Gavin and Hausmann (1996). 
Table 8: Pooled OLS results with interaction terms

\begin{tabular}{|c|c|c|c|c|c|}
\hline \multirow{3}{*}{$\begin{array}{l}\text { Financial } \\
\text { development }\end{array}$} & \multirow[t]{3}{*}{ Variable } & \multicolumn{4}{|c|}{ Output volatility } \\
\hline & & (1) & (2) & (3) & (4) \\
\hline & & 3.1 & 3.2 & 3.3 & 3.4 \\
\hline & Growth & $\begin{array}{l}-0.183^{*} \\
(0.0988)\end{array}$ & $\begin{array}{l}-0.0389 \\
(0.0735)\end{array}$ & $\begin{array}{l}-0.119^{*} \\
(0.0607)\end{array}$ & $\begin{array}{l}-0.0316 \\
(0.0937)\end{array}$ \\
\hline & \multirow[t]{2}{*}{$\mathrm{SD}(\mathrm{TOT})$} & 0.00368 & 0.00781 & $0.00924^{*}$ & 0.00465 \\
\hline & & $(0.00442)$ & $(0.00629)$ & $(0.00689)$ & $(0.00493)$ \\
\hline & \multirow[t]{2}{*}{ SD (INF) } & $0.00140^{* * *}$ & $0.0953^{* * *}$ & $0.0931^{* * *}$ & 0.0102 \\
\hline & & $(0.000234)$ & $(0.0302)$ & $(0.0358)$ & $(0.0642)$ \\
\hline & \multirow[t]{2}{*}{ Openness } & 0.200 & $0.591^{* * *}$ & $0.691^{* * *}$ & $0.617^{* * *}$ \\
\hline & & $(0.186)$ & $(0.192)$ & $(0.197)$ & $(0.228)$ \\
\hline \multirow[t]{4}{*}{ Financial depth } & PC & $\begin{array}{c}-0.00694^{* *} \\
(0.00316)\end{array}$ & & & \\
\hline & \multirow[t]{2}{*}{ PC-SD (TOT) } & 0.00295 & & & \\
\hline & & $(0.00696)$ & & & \\
\hline & PC-SD (INF) & $-0.000125^{* * *}$ & & & \\
\hline \multirow[t]{6}{*}{ Financial efficiency } & \multirow[t]{2}{*}{ NIM } & & $0.111^{*}$ & & \\
\hline & & & $(0.0695)$ & & \\
\hline & \multirow[t]{2}{*}{ NIM-SD (TOT) } & & -0.000349 & & \\
\hline & & & $(0.00139)$ & & \\
\hline & \multirow[t]{2}{*}{ NIM-SD (INF) } & & $-0.00921^{*}$ & & \\
\hline & & & $(0.00537)$ & & \\
\hline \multirow[t]{6}{*}{ Financial stability } & \multirow[t]{2}{*}{ ZS } & & & -0.00664 & \\
\hline & & & & $(0.0102)$ & \\
\hline & \multirow[t]{2}{*}{ ZS-SD (TOT) } & & & -0.000111 & \\
\hline & & & & $(0.000183)$ & \\
\hline & \multirow[t]{2}{*}{ ZS-SD (INF) } & & & $-0.00240^{* *}$ & \\
\hline & & & & $(0.00120)$ & \\
\hline \multirow[t]{16}{*}{ Financial access } & \multirow[t]{2}{*}{ BB } & & & & $-0.0130^{* *}$ \\
\hline & & & & & $(0.00626)$ \\
\hline & \multirow[t]{2}{*}{ BB-SD (TOT) } & & & & -0.00331 \\
\hline & & & & & $(0.00171)$ \\
\hline & \multirow[t]{2}{*}{ BB-SD (INF) } & & & & 0.00393 \\
\hline & & & & & $(0.00356)$ \\
\hline & \multirow[t]{2}{*}{ Constant } & $3.537^{* * *}$ & -0.726 & 0.0342 & -0.135 \\
\hline & & $(1.067)$ & $(1.010)$ & $(0.831)$ & $(1.153)$ \\
\hline & Observations & 523 & 302 & 303 & 202 \\
\hline & R-squared & 0.155 & 0.091 & 0.196 & 0.173 \\
\hline & VIF & 3.53 & 2.76 & 2.44 & 5.37 \\
\hline & Skewness test & 0.0150 & 0.0000 & 0.0000 & 0.4258 \\
\hline & Wald test & 0.0000 & 0.0000 & 0.0000 & 0.0000 \\
\hline & linktest & 0.0000 & 0.0000 & 0.0000 & 0.0000 \\
\hline & ovtest & 0.5211 & 0.1106 & 0.1328 & 0.9677 \\
\hline & Wooldridge's test & 0.5321 & 0.3201 & 0.0632 & 0.1435 \\
\hline
\end{tabular}

Note: Standard errors in parentheses. ${ }^{* *} p<0.01,{ }^{* *} p<0.05, * p<0.1$.

$\mathrm{BB}=$ bank branches, $\mathrm{INF}=$ inflation, $\mathrm{NIM}=$ net interest margin, $\mathrm{PC}=$ private credit to GDP, TOT $=$ terms of trade, $\mathrm{ZS}=\mathrm{z}$-score.

Source: Authors' calculations 
The interaction term PC-SD(INF) combines monetary sector volatility with financial depth (private credit to GDP). Its negative sign in column 1 indicates that financial development helps the monetary sector absorb its volatility. We can assume that financial depth does not aggravate monetary volatility and thus decreases overall output volatility. PC$S D$ (TOT) combines real sector volatility with financial development (private credit to GDP). Its positive sign in column 1 indicates that financial intermediaries magnify real sector volatility, in turn implying that financial development increases volatility in the real sector and thus overall output volatility. However, the evidence is very weak and insignificant.

When net interest margin is used as an indicator of financial development, output volatility is positively correlated with the latter in column 2. While the large number of participants in the financial sector allow it to absorb risk and financial markets to become deeper, the broad participation enables risks to be more widely spread across the economy. As Rajan (2006) argues, changes in the financial sector have changed managerial incentives, which in turn have altered the nature of risks undertaken by the system, with some potential for distortion, thereby increasing output volatility.

The interaction terms in column 2 become negative when the financial development indicator changes from private credit to net interest margin. Their negative sign indicates that financial intermediaries dampen monetary and real sector volatility. Based on this, we can argue that financial development complements the financial and real sectors: it does not aggravate volatility in these sectors and helps decrease overall output volatility. The interaction terms in column 3 become negative when the financial development indicator changes to the z-score. Their negative sign implies that financial intermediaries check monetary and real sector volatility. Again, this would indicate that financial development does not aggravate volatility in these sectors, thereby decreasing overall output volatility, although the evidence is very weak and insignificant. 


\subsection{System GMM Results}

We resolve the problem of endogeneity by using IVs. Although the most common solution is to apply 2SLS, this method is more appropriate in the absence of heteroskedasticity for panel data. To apply system GMM, we take the lag of the dependent variable and instrumented endogenous variables, with legal origin and capital account openness as exogenous instruments, along with internal instruments. We use Sargan's test to gauge the validity of the IVs.

The results in Table 9 suggest that both TOT volatility and inflation volatility magnify output volatility. The volatility of inflation (SD-INF) is significant in column 3 and its coefficients show that an increase in inflation volatility will raise output volatility significantly by nearly 0.41 percent. TOT volatility is significant in column 1 and its coefficients indicate that an increase in TOT volatility will increase output volatility significantly by nearly 6 percent. These results are consistent with our expectations and the literature. The effect of financial intermediary development is negative, which is consistent with most of the literature. The measures of financial depth (private credit to GDP), financial efficiency (net interest margin) and financial access (number of bank branches per 100,000 adults) are negative and significant. 
Table 9: GMM results

\begin{tabular}{|c|c|c|c|c|c|}
\hline \multirow{13}{*}{$\begin{array}{l}\text { Financial } \\
\text { development }\end{array}$} & \multirow[t]{3}{*}{ Variable } & \multicolumn{4}{|c|}{ Output volatility } \\
\hline & & (1) & (2) & (3) & (4) \\
\hline & & 3.1 & $3 . .2$ & 3.3 & 3.4 \\
\hline & \multirow[t]{2}{*}{ L.OV } & $0.261^{*}$ & 0.108 & -0.3267 & $-0.350^{*}$ \\
\hline & & $(0.213)$ & $(0.221)$ & $(0.226)$ & $(0.150)$ \\
\hline & \multirow[t]{2}{*}{ Growth } & 0.141 & -0.0440 & $0.310^{*}$ & 0.224 \\
\hline & & $(0.217)$ & $(0.271)$ & $(0.154)$ & $(0.183)$ \\
\hline & \multirow[t]{2}{*}{$\mathrm{SD}$ (INF) } & -0.000466 & -0.231 & $0.419^{*}$ & -0.0995 \\
\hline & & $(0.00656)$ & $(0.231)$ & $(0.295)$ & $(0.109)$ \\
\hline & \multirow[t]{2}{*}{$\mathrm{SD}(\mathrm{TOT})$} & $-0.0696^{*}$ & 0.0111 & 0.0115 & 0.00348 \\
\hline & & $(0.0408)$ & $(0.0231)$ & $(0.0105)$ & $(0.00746)$ \\
\hline & \multirow[t]{2}{*}{ Openness } & $-1.528^{*}$ & -0.496 & -1.141 & $-1.654^{*}$ \\
\hline & & $(0.896)$ & $(1.014)$ & $(1.138)$ & $(1.119)$ \\
\hline \multirow[t]{6}{*}{ Financial depth } & \multirow[t]{2}{*}{ PC } & $-0.735^{*}$ & & & \\
\hline & & $(0.411)$ & & & \\
\hline & \multirow[t]{2}{*}{ PC-SD (TOT) } & $0.0235^{*}$ & & & \\
\hline & & $(0.0123)$ & & & \\
\hline & \multirow[t]{2}{*}{ PC-SD (INF) } & 0.000152 & & & \\
\hline & & $(0.00229)$ & & & \\
\hline \multirow[t]{6}{*}{ Financial efficiency } & \multirow{2}{*}{\multicolumn{2}{|c|}{ NIM }} & -0.0971 & & \\
\hline & & & $(0.269)$ & & \\
\hline & \multirow{2}{*}{\multicolumn{2}{|c|}{ NIM-SD (TOT) }} & -0.000242 & & \\
\hline & & & $(0.00520)$ & & \\
\hline & \multicolumn{2}{|l|}{ NIM-SD (INF) } & 0.0413 & & \\
\hline & & & $(0.0565)$ & & \\
\hline \multirow[t]{6}{*}{ Financial stability } & \multirow{2}{*}{\multicolumn{2}{|c|}{ ZS }} & & 0.0464 & \\
\hline & & & & $(0.0365)$ & \\
\hline & \multirow{2}{*}{\multicolumn{2}{|c|}{ ZS-SD (TOT) }} & & -0.000149 & \\
\hline & & & & (0.000518) & \\
\hline & \multirow{2}{*}{\multicolumn{2}{|c|}{ ZS-SD (INF) }} & & $-0.0152^{*}$ & \\
\hline & & & & $(0.00859)$ & \\
\hline \multirow[t]{15}{*}{ Financial access } & \multirow{2}{*}{\multicolumn{2}{|c|}{ BB }} & & & $-0.0511^{* *}$ \\
\hline & & & & & $(0.0233)$ \\
\hline & \multirow{2}{*}{\multicolumn{2}{|c|}{ BB-SD (TOT) }} & & & 0.00401 \\
\hline & & & & & $(0.000346)$ \\
\hline & BB-SD (INF) & & & & $0.0273^{* * *}$ \\
\hline & & & & & $(0.00978)$ \\
\hline & Constant & $9.397^{* *}$ & 4.611 & 3.422 & 7.217 \\
\hline & & (3.655) & $(3.724)$ & $(4.172)$ & $(4.909)$ \\
\hline & Observations & 514 & 296 & 223 & 198 \\
\hline & Countries & 76 & 75 & 75 & 69 \\
\hline & $\mathrm{AR}(1)$ & 0.004 & 0.048 & 0.068 & 0.071 \\
\hline & AR (2) & 0.969 & 0.498 & 0.350 & 0.323 \\
\hline & Sargan's test & 0.909 & 0.885 & 0.609 & 0.562 \\
\hline & Overid test & 0.20 & 0.25 & 0.15 & 0.12 \\
\hline & Time dummies & Yes & Yes & Yes & Yes \\
\hline
\end{tabular}

Note: Standard errors in parentheses. ${ }^{* * *} p<0.01,{ }^{* *} p<0.05, * p<0.1$.

$\mathrm{BB}=$ bank branches, $\mathrm{INF}=$ inflation, $\mathrm{NIM}=$ net interest margin, $\mathrm{PC}=$ private credit to GDP, TOT $=$ terms of trade, $\mathrm{ZS}=\mathrm{z}$-score.

Source: Authors' calculations 
These results indicate that financial development helps mitigate output volatility. We find weak evidence to support the dampening effect of financial intermediary development on TOT volatility, given that the interaction terms yield mixed signs and insignificant coefficients ranging from 0.01 (column 3) to 2 percent (column 1). There is somewhat stronger evidence to show that financial development magnifies inflation volatility: the results in columns 1,2 and 4 are positive, with coefficients ranging from 0.018 (column 1) to 4 percent (column 2). The relationship between financial development and output volatility appears to be negative, with real and monetary volatility positively correlated with output volatility. Overall, these results provide only weak evidence that, for a given country, the impact of TOT volatility and inflation volatility diminishes as it develops better financial intermediaries.

For the GMM estimator to be consistent, both instruments chosen from among the lagged endogenous and explanatory variables as well as the assumption that the error terms do not exhibit serial correlation must be valid. To address these issues, we employ Sargan's test, as suggested by Arellano and Bond (1991), Arellano and Bover (1995), and Blundell and Bond (1998). The hypothesis being tested is that the IVs are uncorrelated with a given set of residuals and are therefore acceptable instruments. Since the p-values are greater than 0.1, we cannot reject the null hypothesis and thus conclude that all the instruments are sound.

The purpose of the Arellano-Bond autocorrelation test is to gauge if the error term in levels is not autocorrelated. The values reported for AR (1) and AR (2) are the p-values for first-order and second-order autocorrelated disturbances in the first-differenced equation. Since the $\mathrm{p}$ values are greater than 0.1 for AR (2), we cannot reject the null hypothesis and conclude that all the error terms are uncorrelated. The issue of weak instruments is important to explore because asymptotic theory may be a poor guide to actual finite sample distributions in the presence of weak instruments. In the case of a finite sample, IV estimators may be biased even when they are consistent.

Three issues arise in relation to finite sample bias (Davidson \& MacKinnon, 2004). First, when the number of instruments is very large compared to the sample size, the IV estimators may approach OLS estimators and create a similar bias. While this is not important in crosssection analyses, it matters in the case of panel data IV estimators such as the Arellano-Bond estimator. To address this, we restrict the number of instruments. In the case of instrument proliferation, the over-identification 
test values approach 1 . In our estimations, these values are less than 1 (Table 10). Second, when the correlation between the structural equation error term $u$ and some components of the vector $v$ (first-stage equation errors) is high, then asymptotic theory may be a poor guide to finite sample distributions. Third, in the case of weak instruments, first-stage regressions have a poor fit, which also implies that asymptotic theory is likely a poor guide to the finite sample distribution of the IV estimator.

We follow different approaches to investigate the weak IV problem. The F-statistic shows that the chosen instruments are jointly significant (Table 6). Staiger and Stock (1997) argue that an F-statistic of less than 10 indicates weak instruments. However, this criterion may not be conservative enough when there are many over-identification restrictions. The high values of the R-squared term in the case of the IV estimations (Table 6) indicate that the instruments are not weak. The p-values (Sargan's test) and J-statistics indicate that the instruments are jointly significant and valid. Finally, the p-values generated by Cragg and Donald's (1993) F-statistics also support the validity of the instruments.

\subsection{Pooled OLS Results with Dummy and Interaction Term}

Table 10 reports the results of the pooled OLS regression when we include the interaction term combining financial development with a dummy for developed countries. The dummy helps gauge whether the role of financial development differs between developed and developing countries in reducing or magnifying output volatility, or whether it has no significant effect at all. 
Table 10: Pooled OLS results with interaction of financial development indicators

\begin{tabular}{|c|c|c|c|c|c|}
\hline \multirow{2}{*}{$\begin{array}{l}\text { Financial } \\
\text { development }\end{array}$} & \multirow[t]{2}{*}{ Variable } & \multicolumn{4}{|c|}{ Output volatility } \\
\hline & & (1) & (2) & (3) & (4) \\
\hline & Growth & $-0.182^{* *}$ & -0.0412 & $-0.116^{*}$ & -0.0373 \\
\hline & & $(0.0920)$ & $(0.0763)$ & $(0.0621)$ & $(0.0969)$ \\
\hline & $\mathrm{SD}$ (INF) & 0.00485 & $0.00628^{* *}$ & $0.00649^{* *}$ & $0.00526^{*}$ \\
\hline & & $(0.00380)$ & $(0.00283)$ & $(0.00282)$ & $(0.00313)$ \\
\hline & $\mathrm{SD}(\mathrm{TOT})$ & 0.000238 & $0.0656^{* *}$ & $0.0594^{*}$ & 0.0371 \\
\hline & & $(0.000355)$ & $(0.0318)$ & $(0.0318)$ & $(0.0481)$ \\
\hline & Openness & 0.162 & $0.556^{* * *}$ & $0.686^{* * *}$ & $0.580^{* *}$ \\
\hline & & $(0.210)$ & $(0.197)$ & $(0.198)$ & $(0.245)$ \\
\hline \multirow[t]{6}{*}{ Financial depth } & Dummy & -0.282 & & & \\
\hline & & $(0.345)$ & & & \\
\hline & PC & -0.00569 & & & \\
\hline & & $(0.00392)$ & & & \\
\hline & PC-D & -0.000458 & & & \\
\hline & & $(0.00478)$ & & & \\
\hline \multirow[t]{6}{*}{ Financial efficiency } & Dummy & & -0.447 & & \\
\hline & & & $(0.339)$ & & \\
\hline & NIM & & 0.0268 & & \\
\hline & & & $(0.0482)$ & & \\
\hline & NIM-D & & 0.0743 & & \\
\hline & & & $(0.0699)$ & & \\
\hline \multirow[t]{6}{*}{ Financial stability } & Dummy & & & -0.238 & \\
\hline & & & & $(0.377)$ & \\
\hline & ZS & & & $-0.0188^{*}$ & \\
\hline & & & & $(0.00966)$ & \\
\hline & ZS-D & & & -0.000987 & \\
\hline & & & & $(0.0229)$ & \\
\hline \multirow[t]{10}{*}{ Financial access } & Dummy & & & & 0.492 \\
\hline & & & & & $(0.338)$ \\
\hline & $\mathrm{BB}$ & & & & 0.00116 \\
\hline & & & & & $(0.00820)$ \\
\hline & BB-D & & & & $-0.0182^{*}$ \\
\hline & & & & & $(0.00961)$ \\
\hline & Constant & $3.702^{* * *}$ & -0.208 & 0.325 & -0.202 \\
\hline & & $(0.922)$ & $(1.001)$ & $(0.846)$ & (1.173) \\
\hline & Observations & 523 & 302 & 303 & 202 \\
\hline & R-squared & 0.056 & 0.089 & 0.096 & 0.086 \\
\hline
\end{tabular}

Note: $\mathrm{BB}=$ bank branches, $\mathrm{INF}=$ inflation, $\mathrm{NIM}=$ net interest margin, $\mathrm{PC}=$ private credit to GDP, TOT = terms of trade, $\mathrm{ZS}=\mathrm{z}$-score.

Source: Authors' calculations 
In columns 1 and 3 , the coefficients of the interaction terms (dummy with private credit to GDP and dummy with z-score, respectively) are negative and statistically insignificant. This implies we cannot accept the hypothesis that private credit to GDP and z-scores have a stronger negative relationship with reducing output volatility in developed countries compared to developing ones. Specifically, for every extra US $\$ 1$ increase in private credit to GDP (financial depth), we will see a 0.000458-point decrease in output volatility in developed countries over and above any effect we see in developing countries. The results in column 1 show that every US $\$ 1$ increase in private credit to GDP leads to a $(-0.000458+-0.00569=$ -0.00615)-point decrease in output volatility in developed countries, whereas, a one-point increase in the z-score (financial stability) yields a $(-0.0188+-0.000987=-0.01979)$-point decrease in output volatility in developed countries.

In column 2, the coefficient of the interaction term is positive and statistically insignificant, indicating that we cannot accept the hypothesis that net interest margin as a measure of financial efficiency has a strong positive relationship with magnifying output volatility in developed countries compared to developing ones. Specifically, for every one-unit increase in net interest margin, we will see 0.0743 -point increase in output volatility in developed countries over and above any effect we see in developing countries. In this case, every one-unit increase in net interest margin leads to a $(0.0743+0.0268=0.1011)$-point increase in output volatility in developed countries.

In column 4, the coefficient of the interaction term is negative and statistically significant, implying that we can accept the hypothesis that the number of bank branches as a measure of financial access has a stronger negative relationship with magnifying output volatility in developed countries compared to developing ones. Specifically, for every one-unit increase in the number of bank branches per 100,000 adults, we will see a 0.0182-point decrease in output volatility in developed countries over and above any effect we see in developing countries. In this case, every additional branch per 100,000 adults leads to a $(-0.0182+0.00116=$ -0.01704 ) -point decrease in output volatility in developed countries. These results indicate that financial access is the only significant determinant of financial development leading to a decrease in output volatility when a developed country dummy is introduced. The other measures of financial development do not have a significant effect in this context. 


\subsection{Random Effects and Fixed Effects Results}

Finally, we address the issue of unobserved country-specific effects. Table 11 reports the empirical results of the random effects model. All measures of financial development help mitigate output volatility, except for financial efficiency, which is insignificant. Overall, the results suggest that our baseline findings are not sensitive to random effects.

Table 11: Random effects model

\begin{tabular}{|c|c|c|c|c|c|}
\hline \multirow{2}{*}{$\begin{array}{l}\text { Financial } \\
\text { development }\end{array}$} & \multirow[t]{2}{*}{ Variable } & \multicolumn{4}{|c|}{ Output volatility } \\
\hline & & (1) & (2) & (3) & (4) \\
\hline & \multirow[t]{2}{*}{ Growth } & $-0.208^{* *}$ & -0.0629 & $-0.122^{*}$ & -0.0176 \\
\hline & & $(0.0981)$ & $(0.0792)$ & $(0.0626)$ & $(0.0967)$ \\
\hline & \multirow[t]{2}{*}{$\mathrm{SD}(\mathrm{TOT})$} & 0.00350 & $0.00555^{*}$ & $0.00637^{* *}$ & 0.00493 \\
\hline & & $(0.00382)$ & $(0.00285)$ & $(0.00282)$ & $(0.00312)$ \\
\hline & \multirow[t]{2}{*}{$\mathrm{SD}$ (INF) } & 0.000272 & $0.0658^{* *}$ & $0.0610^{*}$ & 0.0410 \\
\hline & & $(0.000353)$ & $(0.0320)$ & $(0.0319)$ & $(0.0482)$ \\
\hline & \multirow[t]{2}{*}{ Openness } & 0.156 & $0.591^{* * *}$ & $0.679^{* * *}$ & $0.635^{* * *}$ \\
\hline & & $(0.223)$ & $(0.205)$ & $(0.202)$ & $(0.244)$ \\
\hline \multirow[t]{2}{*}{ Financial depth } & \multirow[t]{2}{*}{$\mathrm{PC}$} & -0.00546 & & & \\
\hline & & $(0.00346)^{* * *}$ & & & \\
\hline \multirow{2}{*}{$\begin{array}{l}\text { Financial } \\
\text { efficiency }\end{array}$} & \multirow[t]{2}{*}{ NIM } & & 0.0498 & & \\
\hline & & & $(0.0448)$ & & \\
\hline \multirow[t]{2}{*}{ Financial stability } & \multirow[t]{2}{*}{ ZS } & & & $-0.0169^{* *}$ & \\
\hline & & & & $(0.00846)$ & \\
\hline \multirow[t]{6}{*}{ Financial access } & \multirow[t]{2}{*}{ BB } & & & & $-0.00919^{* * *}$ \\
\hline & & & & & $(0.00597)$ \\
\hline & \multirow[t]{2}{*}{ Constant } & $3.865^{* * *}$ & -0.304 & 0.290 & -0.377 \\
\hline & & $(0.972)$ & $(1.042)$ & $(0.868)$ & $(1.162)$ \\
\hline & Observations & 523 & 302 & 303 & 202 \\
\hline & R-squared & 0.28 & 0.25 & 0.27 & 0.20 \\
\hline
\end{tabular}

Note: $\mathrm{BB}=$ bank branches, $\mathrm{INF}=$ inflation, $\mathrm{NIM}=$ net interest margin, $\mathrm{PC}=$ private credit to GDP, TOT = terms of trade, $\mathrm{ZS}=\mathrm{z}$-score.

Source: Authors' calculations

A fixed effects model is used to address country heterogeneity by controlling for country-specific effects. Table 12 replicates the baseline model with fixed effects. The first column shows that the effect of financial depth is positive and significant, implying that it increases output volatility. The other measures of financial development have no significant impact on output volatility. Overall, the role of financial development is mixed and the variable is sensitive to alternative estimators. 
Table 12: Fixed effects model

\begin{tabular}{|c|c|c|c|c|c|}
\hline \multirow{2}{*}{$\begin{array}{l}\text { Financial } \\
\text { development }\end{array}$} & \multirow[t]{2}{*}{ Variable } & \multicolumn{4}{|c|}{ Output volatility } \\
\hline & & (1) & (2) & (3) & (4) \\
\hline & \multirow[t]{2}{*}{ Growth } & $-1.193^{* *}$ & 0.163 & 0.177 & -1.387 \\
\hline & & $(0.579)$ & $(0.849)$ & $(0.855)$ & $(1.575)$ \\
\hline & \multirow[t]{2}{*}{$\mathrm{SD}(\mathrm{TOT})$} & -0.00104 & 0.000239 & 0.000146 & -0.000144 \\
\hline & & $(0.00445)$ & $(0.00438)$ & $(0.00432)$ & $(0.00735)$ \\
\hline & \multirow[t]{2}{*}{ SD (INF) } & 0.000330 & 0.0534 & 0.0550 & -0.0140 \\
\hline & & $(0.000365)$ & $(0.0401)$ & $(0.0399)$ & $(0.0710)$ \\
\hline & \multirow[t]{2}{*}{ Openness } & -0.427 & -0.202 & -0.0514 & 0.474 \\
\hline & & $(0.534)$ & $(0.755)$ & $(0.755)$ & $(1.290)$ \\
\hline \multirow[t]{2}{*}{ Financial depth } & \multirow[t]{2}{*}{ PC } & $0.00965^{*}$ & & & \\
\hline & & $(0.00568)$ & & & \\
\hline \multirow{2}{*}{$\begin{array}{l}\text { Financial } \\
\text { efficiency }\end{array}$} & \multirow[t]{2}{*}{ NIM } & & 0.0132 & & \\
\hline & & & $(0.0948)$ & & \\
\hline \multirow[t]{2}{*}{ Financial stability } & \multirow[t]{2}{*}{ ZS } & & & -0.00646 & \\
\hline & & & & $(0.0284)$ & \\
\hline \multirow[t]{6}{*}{ Financial access } & \multirow[t]{2}{*}{$\mathrm{BB}$} & & & & -0.00274 \\
\hline & & & & & $(0.0329)$ \\
\hline & \multirow[t]{2}{*}{ Constant } & $13.62^{* * *}$ & 1.459 & 0.860 & 12.25 \\
\hline & & $(4.225)$ & (7.109) & (7.153) & (13.90) \\
\hline & Observations & 523 & 302 & 303 & 202 \\
\hline & R-squared & 0.15 & 0.55 & 0.02 & 0.03 \\
\hline
\end{tabular}

Note: $\mathrm{BB}=$ bank branches, $\mathrm{INF}=$ inflation, $\mathrm{NIM}=$ net interest margin, $\mathrm{PC}=$ private credit to GDP, TOT = terms of trade, $\mathrm{ZS}=\mathrm{z}$-score.

Source: Authors' calculations

Tables 13 and 14 summarize the overall effects of financial development on output volatility comparing the cross-sectional, pooled OLS and GMM results.

Table 13: Summary of results without interaction terms

\begin{tabular}{lccc}
\hline Variable & Cross-section & Pooled OLS & Overall \\
\hline PC & - & - & - \\
NIM & + & + & + \\
ZS & - & - & - \\
BB & + & - & Mixed \\
SD (TOT) & + & + & + \\
SD (INF) & + & + & + \\
\hline
\end{tabular}

Note: $\mathrm{BB}=$ bank branches, $\mathrm{INF}=$ inflation, $\mathrm{NIM}=$ net interest margin, $\mathrm{PC}=$ private credit to GDP, TOT = terms of trade, $\mathrm{ZS}=\mathrm{z}$-score.

Source: Authors' calculations 
Table 14: Summary of results with interaction terms

\begin{tabular}{lccccc}
\hline Variable & $\begin{array}{c}\text { Cross- } \\
\text { section }\end{array}$ & Pooled OLS & GMM & 2SLS & Overall \\
\hline PC & + & - & - & + & Mixed \\
NIM & - & + & - & - & - \\
ZS & - & - & + & - & - \\
BB & + & - & - & + & Mixed \\
SD (TOT) & + & + & + & + & + \\
SD (INF) & - & + & - & ++- - & - \\
PC-SD (TOT) & - & + & + & - & Mixed \\
NIM-SD (TOT) & + & - & - & + & Mixed \\
ZS-SD (TOT) & - & - & - & - & - \\
BB-SD (TOT) & - & - & + & - & - \\
PC-SD (INF) & - & - & + & - & - \\
NIM-SD (INF) & + & - & + & + & + \\
ZS-SD (INF) & + & - & - & - & - \\
BB-SD (INF) & + & + & + & - & + \\
\hline
\end{tabular}

Note: $\mathrm{BB}=$ bank branches, $\mathrm{INF}=$ inflation, $\mathrm{NIM}=$ net interest margin, $\mathrm{PC}=$ private credit to GDP, TOT = terms of trade, $\mathrm{ZS}=\mathrm{z}$-score.

Source: Authors' calculations

\section{Conclusion and Policy Recommendations}

Globally high levels of output volatility have raised serious concerns among economists and policymakers. The problem is not only that output volatility hinders sustained and rapid economic growth, but that it also constrains development in general. Financial development has been a key economic and institutional change: it promotes better credit allocation and eases borrowing constraints, which helps reduce the impact of nonfinancial shocks on aggregate output and investment. Our findings show that financial development can have an increasing or decreasing effect on output volatility, depending on which measure is used. Overall, we find evidence of a negative relationship. Financial depth, financial access and financial stability have negative signs and help mitigate output volatility. The role of financial efficiency and financial access in mitigating output volatility is weaker than that of financial depth.

On including interaction terms, we derive mixed results: financial efficiency and financial stability are negatively related to output volatility, while financial depth and financial access are positively related to output volatility. Financial efficiency itself reduces output volatility, but its interaction with monetary sector volatility has a positive sign, indicating that 
financial efficiency does not help reduce monetary sector volatility. It appears to play a mixed role, however, in aggravating real sector volatility.

Financial stability is negatively related to output volatility and also helps mitigate volatility in the real and monetary sectors. This shows that financial stability not only reduces output fluctuations directly, but also helps reduce volatility in both sectors. Here, the financial depth variable generates mixed results when considered directly as well as interactively. On the other hand, the financial access interaction term with real sector volatility shows that access helps mitigate real sector volatility. Its interaction with monetary sector volatility shows that financial access magnifies the volatility of the monetary sector. We could also interpret this interaction in view of recent research indicating the negative impact of inflation on financial sector development (see Boyd et al., 2001). This interpretation would characterize inflation volatility as decreasing the ability of financial intermediaries to absorb shocks and thus its capacity to reduce output volatility.

Overall, our results suggest that financial development helps mitigate output volatility, although the evidence remains weak in some cases. We find that financial stability plays a more prominent role in decreasing output volatility than other measures of financial development. The positive sign of real and monetary sector volatility implies that volatility in both sectors contributes significantly to making output more volatile. Finally, our results do not imply that financial sector policies are irrelevant to volatility. Rather, the financial sector plays an important role in smoothing out output fluctuations. In this context, the ownership structure of the banking system, the integration of domestic financial markets with international capital markets, and the regulatory and supervisory framework for banks, among other determinants, could have an important impact on mitigating output volatility.

While these results are strongly suggestive, they do not provide unconditional proof. We do not find any robust interaction between the financial development indicators and our measures of real and monetary volatility. This could be due to the weakness of the indicators (TOT volatility and inflation volatility) or to the limited relevance of this channel. Our empirical analysis should, therefore, be seen as exploratory rather than as providing definite answers.

The study is bound by certain limitations. First, it is inappropriate to generalize from only two proxies for real and monetary shocks. Future 
research could, therefore, analyze alternative channels through which financial intermediaries affect output volatility and identify other IVs to improve the quality of results. Second, our findings are sensitive to the fixed effects estimator.

Policy measures are important for the development of the financial sector, given that the effect of financial intermediaries' development through bank selection and investment monitoring could help attract more beneficial investments and increase economic growth. Better developed financial sectors also help reduce transaction costs and risk, which, in turn, promotes long-term investment and stabilizes the economy. This study finds that financial stability plays a more prominent role in decreasing output volatility than other measures of financial development. This implies a need to focus on policies that would help stabilize the financial sector. The central bank and national government should actively implement policies that increase the soundness of the financial sector by providing guarantees to financial institutions and improving their structure, ensuring transparency and accountability, and easing the credit constraints to the banking industry.

We find that real sector and monetary sector volatility contribute significantly to output volatility. This implies that policies seeking to curb output volatility must also minimize volatility in the real sector as well as the monetary sector. Effective fiscal and monetary policy play an important role in reducing output losses and minimizing output volatility. However, our results do not imply that policymakers should refrain from pursuing policies that foster financial development. Rather, they underline that financial intermediaries are not a universal solution to controlling volatility and that policy should also focus on other possible linkages to output volatility. 


\section{References}

Acemoglu, D., Johnson, S., Robinson, J., \& Thaicharoen, Y. (2003). Institutional causes, macroeconomic symptoms: Volatility, crises and growth. Journal of Monetary Economics, 50(1), 49-123.

Acemoglu, D., \& Zilibotti, F. (1997). Was Prometheus unbound by chance? Risk, diversification, and growth. Journal of Political Economy, 105(4), 709-751.

Aghion, P., Bacchetta, P., \& Banerjee, A. (2000). Capital markets and the instability of open economies. In P.-R. Agénor et al. (eds.), The Asian financial crisis: Causes, contagion and consequences (pp. 167-194). Cambridge: Cambridge University Press.

Aghion, P., Bacchetta, P., \& Banerjee, A. (2004). Financial development and the instability of open economies. Journal of Monetary Economics, 51(6), 1077-1106.

Aghion, P., Banerjee, A., \& Piketty, T. (1999). Dualism and macroeconomic volatility. Quarterly Journal of Economics, 114(4), 1359-1397.

Ahamada, I., \& Coulibaly, D. (2011). How does financial development influence the impact of remittances on growth volatility? Economic Modelling, 28(6), 2748-2760.

Andersen, T. B., \& Tarp, F. (2003). Financial liberalization, financial development and economic growth in LDCs. Journal of International Development, 15(2), 189-209.

Ang, J. B. (2011). Finance and consumption volatility: Evidence from India. Journal of International Money and Finance, 30(6), 947-964.

Arellano, M., \& Bond, S. (1991). Some tests of specification for panel data: Monte Carlo evidence and an application to employment equations. Review of Economic Studies, 58(2), 277-297.

Arellano, M., \& Bover, O. (1995). Another look at the instrumental variable estimation of error-components models. Journal of Econometrics, 68(1), 29-51. 
Bacchetta, P., \& Caminal, R. (2000). Do capital market imperfections exacerbate output fluctuations? European Economic Review, 44(3), 449-468.

Beck, T., \& Levine, R. (2004). Stock markets, banks, and growth: Panel evidence. Journal of Banking and Finance, 28(3), 423-442.

Beck, T., Levine, R., \& Loayza, N. (2000). Finance and the sources of growth. Journal of Financial Economics, 58(1-2), 261-300.

Beck, T., Lundberg, M., \& Majnoni, G. (2006). Financial intermediary development and growth volatility: Do intermediaries dampen or magnify shocks? Journal of International Money and Finance, 25(7), 1146-1167.

Bekaert, G., Harvey, C. R., \& Lundblad, C. (2006). Growth volatility and financial liberalization. Journal of International Money and Finance, 25(3), 370-403.

Bencivenga, V. R., \& Smith, B. D. (1991). Financial intermediation and endogenous growth. Review of Economic Studies, 58(2), 195-209.

Bernanke, B., \& Gertler, M. (1989). Agency costs, net worth, and business fluctuations. American Economic Review, 79(1), 14-31.

Bleaney, M., \& Fielding, D. (2002). Exchange rate regimes, inflation and output volatility in developing countries. Journal of Development Economics, 68(1), 233-245.

Blundell, R., \& Bond, S. (1998). Initial conditions and moment restrictions in dynamic panel data models. Journal of Econometrics, 87(1), 115143.

Boyd, J. H., Levine, R., \& Smith, B. D. (2001). The impact of inflation on financial sector performance. Journal of Monetary Economics, 47(2), 221-248.

Brunnermeier, M. K., Eisenbach, T. M., \& Sannikov, Y. (2012). Macroeconomics with financial frictions: A survey (Working Paper No. 18102). Cambridge, MA: National Bureau of Economic Research.

Bruno, M., \& Easterly, W. (1998). Inflation crises and long-run growth. Journal of Monetary Economics, 41(1), 3-26. 
Cecchetti, S. G., McConnell, M. M., \& Perez-Quiros, G. (2002). Policymakers' revealed preferences and the output-inflation variability tradeoff: Implications for the European system of central banks. The Manchester School, 70(4), 596-618.

Čihák, M., Demirgüç-Kunt, A., Feyen, E., \& Levine, R. (2012). Benchmarking financial systems around the world (Policy Research Working Paper No. 6175). Washington, DC: World Bank.

Conrad, C., Karanasos, M., \& Zeng, N. (2010). The link between macroeconomic performance and variability in the UK. Economics Letters, 106(3), 154-157.

Cragg, J. G., \& Donald, S. G. (1993). Testing identifiability and specification in instrumental variable models. Econometric Theory, 9(2), 222-240.

Dabla-Norris, E., \& Srivisal, N. (2013). Revisiting the link between finance and macroeconomic volatility (Working Paper No. 13/29). Washington, DC: International Monetary Fund.

Davidson, R., \& MacKinnon, J. G. (2004). Econometric theory and methods. New York: Oxford University Press.

De Gregorio, J., \& Guidotti, P. E. (1995). Financial development and economic growth. World Development, 23(3), 433-448.

Denizer, C. A., Iyigun, M. F., \& Owen, A. (2002). Finance and macroeconomic volatility. Contributions in Macroeconomics, 2(1). https://doi.org/10.2202/1534-6005.1048

Dynan, K. E., Elmendorf, D. W., \& Sichel, D. E. (2006). Can financial innovation help to explain the reduced volatility of economic activity? Journal of Monetary Economics, 53(1), 123-150.

Gavin, M., \& Hausmann, R. (1996). Sources of macroeconomic volatility in developing economies (Working paper). Washington, DC: InterAmerican Development Bank.

Gertler, M. (1988). Financial structure and aggregate economic activity: An overview. Journal of Money, Credit and Banking, 20(3), 25-50.

Goldsmith, R. W. (1969). Financial structure and development. New Haven, CT: Yale University Press. 
Greene, W. H. (1997). Econometric analysis. New York: Pearson.

Greenwood, J., \& Jovanovic, B. (1990). Financial development, growth, and the distribution of income. Journal of Political Economy, 98(5), 10761107.

Greenwood, J., \& Smith, B. D. (1997). Financial markets in development, and the development of financial markets. Journal of Economic Dynamics and Control, 21(1), 145-181.

Greenwald, B. C., \& Stiglitz, J. E. (1993). Financial market imperfections and business cycles. Quarterly Journal of Economics, 108(1), 77-114.

Haddad, M., Lim, J. J., Pancaro, C., \& Saborowski, C. (2013). Trade openness reduces growth volatility when countries are well diversified. Canadian Journal of Economics, 46(2), 765-790.

Hakura, D. (2007). Output volatility and large output drops in emerging market and developing countries (Working Paper 07/114). Washington, DC: International Monetary Fund.

Keynes, J. M. (1936). The general theory of employment, interest and money. London: Macmillan.

King, R. G., \& Levine, R. (1993). Finance, entrepreneurship and growth: Theory and evidence. Journal of Monetary Economics, 32(3), 513-542.

Kiyotaki, N., \& Moore, J. (1997). Credit cycles. Journal of Political Economy, 105(2), 211-248.

Ko, K. W. (2008). Financial integration, information and communication technology, and macroeconomic volatility: Evidence from ten Asian economies. Research in International Business and Finance, 22(2), 124-144.

Kose, M. A., Prasad, E. S., \& Terrones, M. E. (2006). How do trade and financial integration affect the relationship between growth and volatility? Journal of International Economics, 69(1), 176-202.

Kose, M. A., Prasad, E. S., \& Terrones, M. E. (2009). Does openness to international financial flows raise productivity growth? Journal of International Money and Finance, 28(4), 554-580. 
Krebs, T., Krishna, P., \& Maloney, W. (2005). Trade policy, income risk, and welfare (Working Paper No. 11255). Cambridge, MA: National Bureau of Economic Research.

Levchenko, A. A., Rancière, R., \& Thoenig, M. (2009). Growth and risk at the industry level: The real effects of financial liberalization. Journal of Development Economics, 89(2), 210-222.

Levine, R. (1997). Financial development and economic growth: Views and agenda. Journal of Economic Literature, 35(2), 688-726.

Levine, R., Loayza, N., \& Beck, T. (2000). Financial intermediation and growth: Causality and causes. Journal of Monetary Economics, 46(1), 31-77.

Levine, R., \& Zervos, S. (1998). Stock markets, banks, and economic growth. American Economic Review, 88(3), 537-558.

Loayza, N., \& Hnatkovska, V. V. (2004). Volatility and growth (Policy Research Working Paper No. 3184). Washington, DC: World Bank.

Lucas, R. E. (1988). On the mechanics of economic development. Journal of Monetary Economics, 22(1), 3-42.

Lutz, M. (1994). The effects of volatility in the terms of trade on output growth: New evidence. World Development, 22(12), 1959-1975.

Malik, A., \& Temple, J. R. (2009). The geography of output volatility. Journal of Development Economics, 90(2), 163-178.

Mishkin, F. S. (2009). Is monetary policy effective during financial crises? (Working Paper No. 14678). Cambridge, MA: National Bureau of Economic Research.

Popov, A. (2011). Output growth and fluctuations: The role of financial openness (Working Paper No. 1368). Frankfurt: European Central Bank.

Posch, O. (2011). Explaining output volatility: The case of taxation. Journal of Public Economics, 95(11-12), 1589-1606.

Quadrini, V. (2011). Financial frictions in macroeconomic fluctuations. Economic Quarterly, 97(3), 209-254. 
Rajan, R. G. (2006). Has finance made the world riskier? European Financial Management, 12(4), 499-533.

Ram, R. (1999). Financial development and economic growth: Additional evidence. Journal of Development Studies, 35(4), 164-174.

Ramey, V., \& Ramey, G. (1995). Cross-country evidence on the link between volatility and growth. American Economic Review, 85(5), 1138-1159.

Servén, L. (2002). Real exchange rate uncertainty and private investment in developing countries (Policy Research Working Paper No. 2823). Washington, DC: World Bank.

Shleifer, A., \& Vishny, R. W. (2010). Unstable banking. Journal of Financial Economics, 97(3), 306-318.

Singer, H., \& Edström, J. (1993). The impact of trends and volatility in terms of trade on GNP growth. In M. Nissanke \& A. Hewitt (eds.), Economic crisis in developing countries: New perspectives on commodities, trade, and finance. New York: Pinter.

Staiger, D., \& Stock, J. H. (1997). Instrumental variables regression with weak instruments. Econometrica, 65(3), 557-586.

Stern, N. (1989). The economics of development: A survey. Economic Journal, 99(397), 597-685.

Wagner, W. (2010). Diversification at financial institutions and systemic crises. Journal of Financial Intermediation, 19(3), 373-386.

Wurgler, J. (2000). Financial markets and the allocation of capital. Journal of Financial Economics, 58(1-2), 187-214. 


\section{Appendix}

Table A1: Description of variables

\begin{tabular}{|c|c|c|}
\hline Abbreviation & Variable & Definition \\
\hline GDP & GDP per capita & $\begin{array}{l}\text { GDP divided by midyear population. GDP is } \\
\text { the sum of gross value added by all resident } \\
\text { producers in the economy plus any product } \\
\text { taxes and minus any subsidies not included in } \\
\text { the value of the products. It is calculated } \\
\text { without making deductions for depreciation of } \\
\text { fabricated assets or for depletion and } \\
\text { degradation of natural resources. Data in } \\
\text { constant } 2005 \text { US dollars. }\end{array}$ \\
\hline \multirow[t]{3}{*}{ OV } & $\begin{array}{l}\text { GDP per capita } \\
\text { growth }\end{array}$ & $\begin{array}{l}\text { Annual percentage growth rate of GDP per } \\
\text { capita based on constant local currency. } \\
\text { Aggregates are based on constant } 2005 \text { US } \\
\text { dollars. }\end{array}$ \\
\hline & Import value & $\begin{array}{l}\text { Import value indexes are the current value of } \\
\text { imports (c.i.f.) converted to US dollars and } \\
\text { expressed as a percentage of the average for the } \\
\text { base period (2000). UNCTAD's import value } \\
\text { indexes are reported for most economies. For } \\
\text { selected economies for which UNCTAD does } \\
\text { not publish data, the import value indexes are } \\
\text { derived from import volume indexes (line 73) } \\
\text { and corresponding unit value indexes of } \\
\text { imports (line 75) in the IMF's International } \\
\text { Financial Statistics. }\end{array}$ \\
\hline & Export value & $\begin{array}{l}\text { Export values are the current value of exports } \\
\text { (f.o.b.) converted to US dollars and expressed } \\
\text { as a percentage of the average for the base } \\
\text { period (2000). UNCTAD's export value indexes } \\
\text { are reported for most economies. For selected } \\
\text { economies for which UNCTAD does not } \\
\text { publish data, the export value indexes are } \\
\text { derived from export volume indexes (line } 72 \text { ) } \\
\text { and corresponding unit value indexes of } \\
\text { exports (line 74) in the IMF's International } \\
\text { Financial Statistics. }\end{array}$ \\
\hline INF & $\begin{array}{l}\text { Consumer price } \\
\text { index }(2010=100)\end{array}$ & $\begin{array}{l}\text { Consumer price index reflects changes in the } \\
\text { cost to the average consumer of acquiring a } \\
\text { basket of goods and services that may be fixed } \\
\text { or changed at specified intervals, such as } \\
\text { yearly. The Laspeyres formula is generally } \\
\text { used. Data are period averages. }\end{array}$ \\
\hline TO & Trade openness & $\begin{array}{l}\text { Imports of goods and services (\% of GDP) + } \\
\text { exports of goods and services (\% of GDP) }\end{array}$ \\
\hline TOT & Terms of trade & Export value/import value ${ }^{*} 100$ \\
\hline
\end{tabular}




\begin{tabular}{|c|c|c|}
\hline Abbreviation & Variable & Definition \\
\hline PC & $\begin{array}{l}\text { Ratio of private } \\
\text { credit to GDP }\end{array}$ & $\begin{array}{l}\text { The financial resources provided to the private } \\
\text { sector by domestic money banks as a share of } \\
\text { GDP. Domestic money banks comprise } \\
\text { commercial banks and other financial } \\
\text { institutions that accept transferable deposits, } \\
\text { such as demand deposits. }\end{array}$ \\
\hline NIM & Net interest margin & $\begin{array}{l}\text { Accounting value of a bank's net interest } \\
\text { revenue as a share of its average interest- } \\
\text { bearing (total earning) assets (Bankscope). }\end{array}$ \\
\hline ZS & Bank's z-score & $\begin{array}{l}\text { Captures the probability of default of a } \\
\text { country's banking system. Z-scores compare } \\
\text { the buffer of a country's banking system } \\
\text { (capitalization and returns) with the volatility } \\
\text { of those returns (Bankscope). }\end{array}$ \\
\hline BB & $\begin{array}{l}\text { Number of bank } \\
\text { branches }\end{array}$ & $\begin{array}{l}\text { Total number of ATMs for every 100,000 adults } \\
\text { in the reporting country. Calculated as (number } \\
\text { of ATMs)*100,000/adult population. }\end{array}$ \\
\hline
\end{tabular}

Source: International Financial Statistics (2014) for financial indicators, remaining indicators from World Development Indicators (2014).

Table A2: List of countries

\begin{tabular}{llllllll}
\hline 1 & Algeria & 21 & Dominican Rep. & 41 & Italy & 61 & Paraguay \\
2 & Argentina & 22 & Ecuador & 42 & Jamaica & 62 & Peru \\
3 & Australia & 23 & Egypt, Arab Rep. & 43 & Japan & 63 & Philippines \\
4 & Austria & 24 & El Salvador & 44 & Jordan & 64 & Portugal \\
5 & Bahamas & 25 & Ethiopia & 45 & Kenya & 65 & Rwanda \\
6 & Barbados & 26 & Finland & 46 & Korea, Rep. & 66 & Senegal \\
7 & Belgium & 27 & France & 47 & Luxembourg & 67 & Singapore \\
8 & Bhutan & 28 & Gabon & 48 & Madagascar & 68 & South Africa \\
9 & Bolivia & 29 & Gambia & 49 & Malta & 69 & Spain \\
10 & Botswana & 30 & Germany & 50 & Mauritius & 70 & Sri Lanka \\
11 & Burkina Faso & 31 & Ghana & 51 & Mexico & 71 & Sudan \\
12 & Burundi & 32 & Greece & 52 & Morocco & 72 & Sweden \\
13 & Cameroon & 33 & Guatemala & 53 & Nepal & 73 & Switzerland \\
14 & Canada & 34 & Haiti & 54 & Netherlands & 74 & Syrian Arab Rep. \\
15 & China & 35 & Honduras & 55 & New Zealand & 75 & Thailand \\
16 & Colombia & 36 & Iceland & 56 & Niger & 76 & Trinidad and \\
& & & & & & & Tobago \\
17 & Costa Rica & 37 & India & 57 & Nigeria & 77 & UK \\
18 & Cote d'lvoire & 38 & Iran, Islamic Rep. 58 & Norway & 78 & US \\
19 & Cyprus & 39 & Ireland & 59 & Pakistan & 79 & Uruguay \\
20 & Denmark & 40 & Israel & 60 & Panama & 80 & \\
\hline
\end{tabular}


Figure A1: Financial development and volatility, developing countries

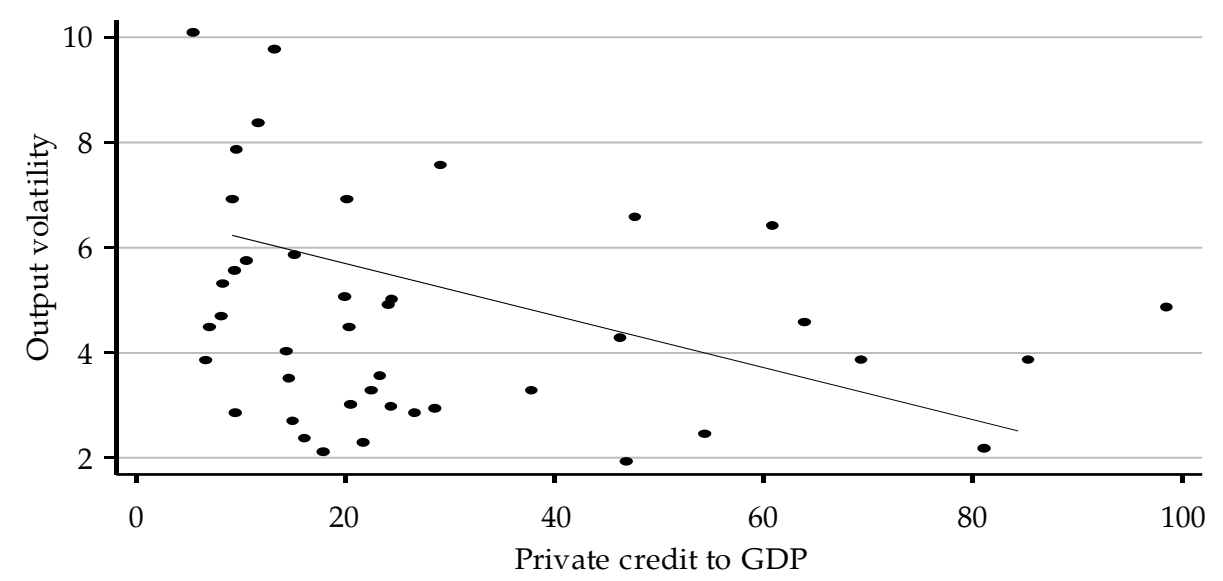

Figure A2: Financial development and volatility, developed countries

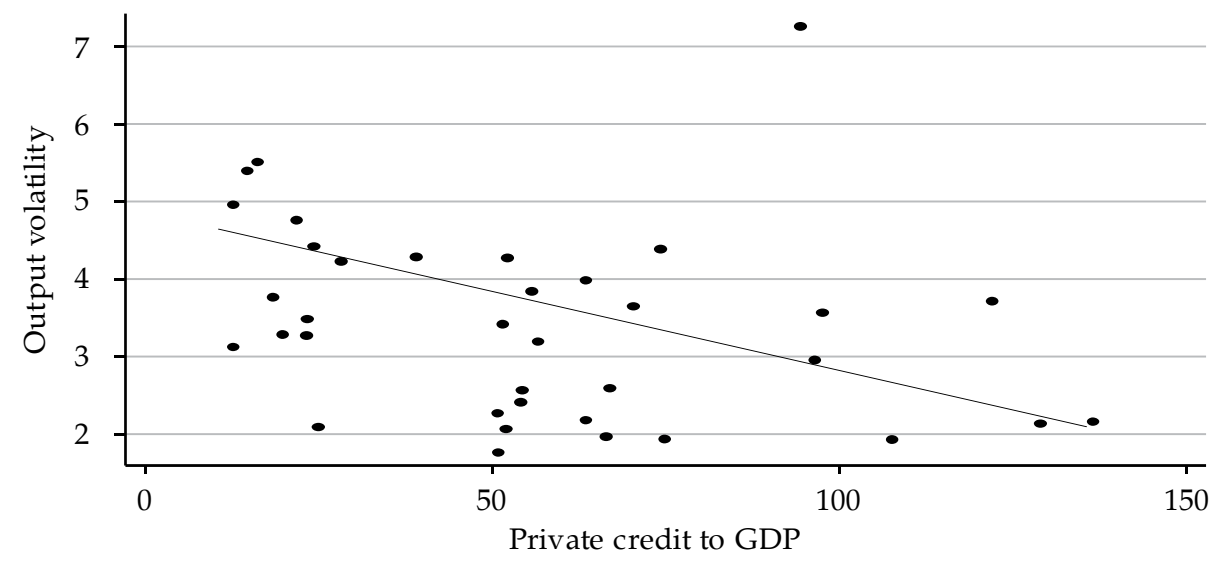

Figure A3: Financial access and output volatility

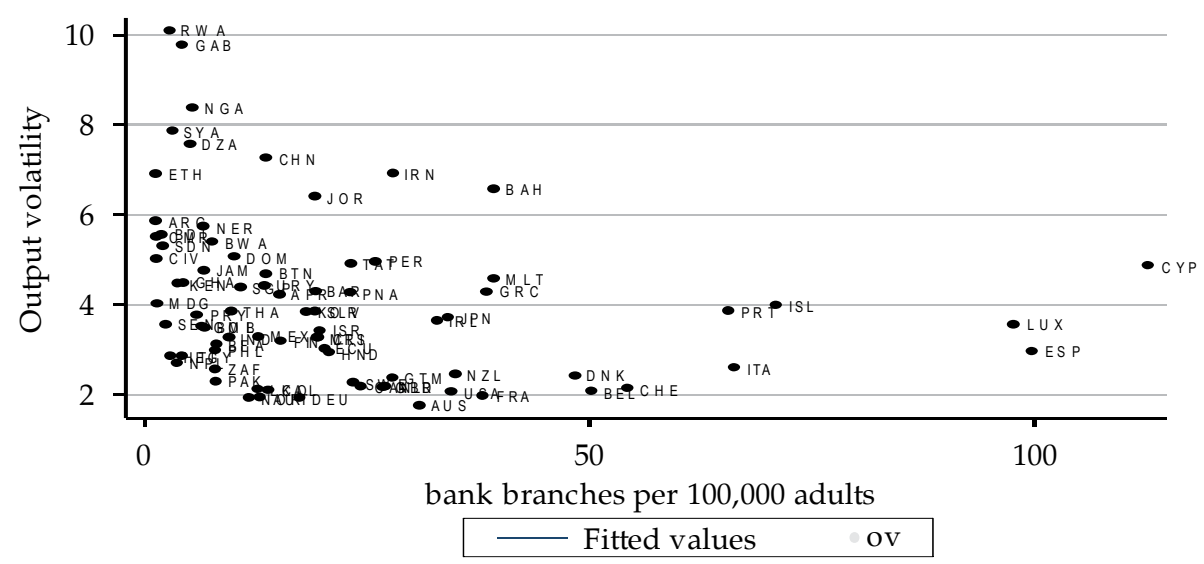


Figure A4: Financial stability and output volatility

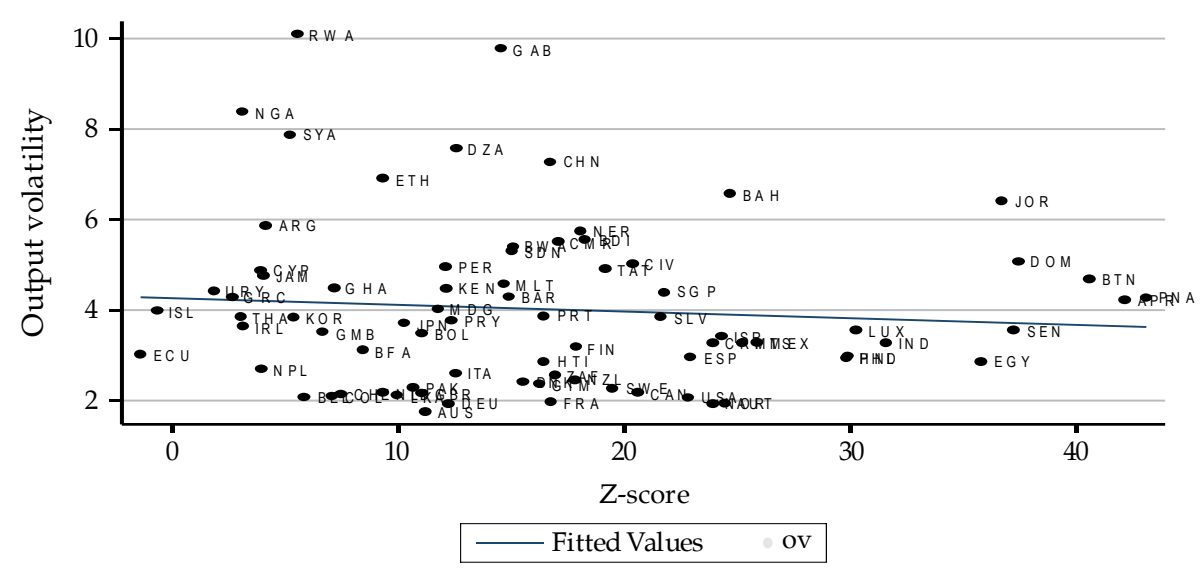

Figure A5: Financial efficiency and output volatility

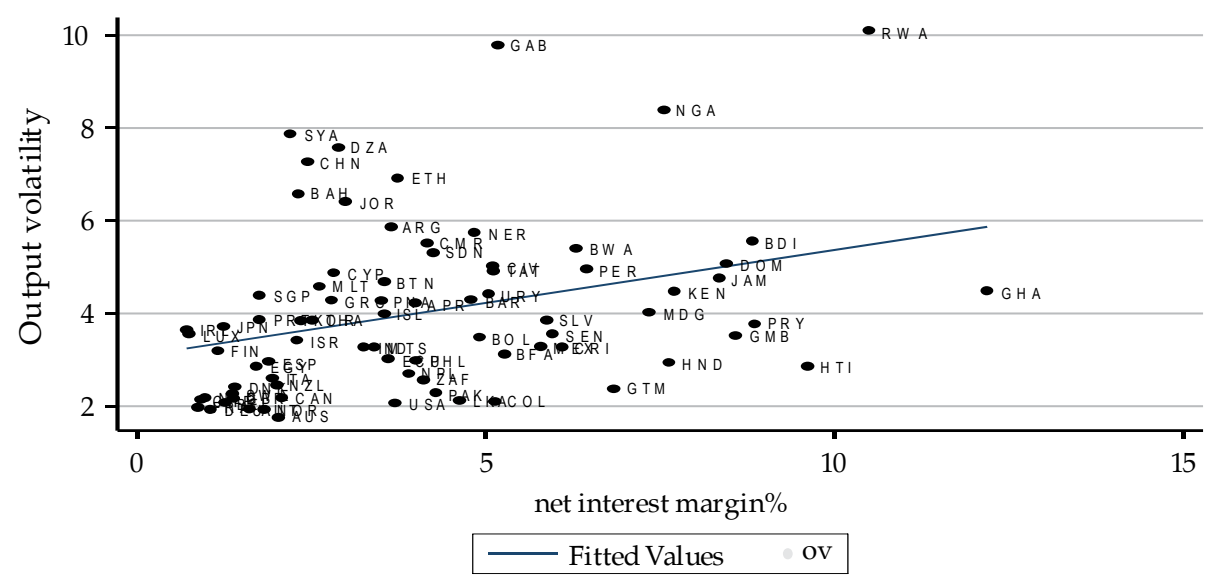

Figure A6: Financial depth and output volatility

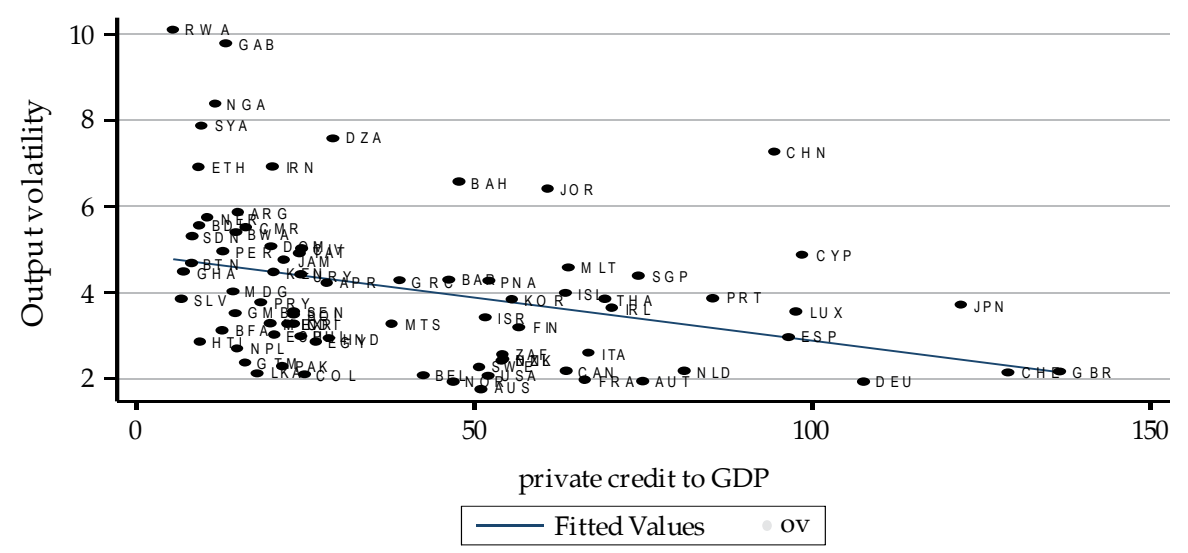

